\title{
The significance of nitrogen regeneration for new production within a filament of the Mauritanian upwelling system
}

\author{
Darren R. Clark, Claire E. Widdicombe, Andrew P. Rees, and E. Malcolm S. Woodward \\ Plymouth Marine Laboratory, Prospect Place, West Hoe, Plymouth, PL1 3DH, UK \\ Correspondence to: D. R. Clark (drcl@pml.ac.uk)
}

Received: 23 October 2015 - Published in Biogeosciences Discuss.: 6 November 2015

Revised: 5 April 2016 - Accepted: 3 May 2016 - Published: 18 May 2016

\begin{abstract}
The Lagrangian progression of a biological community was followed in a filament of the Mauritanian upwelling system, north-west Africa, during offshore advection. The inert dual tracers sulfur hexafluoride and helium-3 labelled a freshly upwelled patch of water that was mapped for 8 days. Changes in biological, physical, and chemical characteristics were measured, including phytoplankton productivity, nitrogen assimilation, and regeneration. Freshly upwelled water contained high nutrient concentrations but was depleted in $\mathrm{N}$ compared to Redfield stoichiometry. The highest rate of primary productivity was measured on the continental shelf, associated with high rates of nitrogen assimilation and a phytoplankton community dominated by diatoms and flagellates. Indicators of phytoplankton abundance and activity decreased as the labelled water mass transited the continental shelf slope into deeper water, possibly linked to the mixed layer depth exceeding the light penetration depth. By the end of the study, the primary productivity rate decreased and was associated with lower rates of nitrogen assimilation and lower nutrient concentrations. Nitrogen regeneration and assimilation took place simultaneously. Results highlighted the importance of regenerated $\mathrm{NH}_{4}^{+}$in sustaining phytoplankton productivity and indicate that the upwelled $\mathrm{NO}_{3}^{-}$pool contained an increasing fraction of regenerated $\mathrm{NO}_{3}^{-}$as it advected offshore. By calculating this fraction and incorporating it into an $f$ ratio formulation, we estimated that of the $12.38 \mathrm{Tg} \mathrm{C}$ of annual regional production, $4.73 \mathrm{Tg} \mathrm{C}$ was exportable.
\end{abstract}

\section{Introduction}

The combination of north-east trade winds and the Coriolis effect due to earth's rotation drives the upwelling of deep nutrient-rich waters into the photic zone of coastal regions in eastern ocean boundaries. Upwelling supports characteristically enhanced biological production and valuable ecosystem services typified by fisheries (Pauly and Christensen, 1995; Arístegui et al., 2009). The maturation and development of biological communities within upwelled water masses as they advect offshore reflects a characteristic feature of eastern boundary upwelling ecosystems (EBUE), the spatial separation of nutrient sources and sinks. Gauging the extent of biological production ultimately exported from upwelling regions is an area of continuing investigation and model development (Álvarez-Salgado et al., 2007; Arístegui et al., 2009).

The north-west African upwelling system is possibly the least studied of the four global EBUEs (California, PeruChile, Iberia and north-west Africa, Benguela) and is potentially the most complex due to its topography and circulation (Mittelstaedt, 1991; Tomczak and Godfrey, 2003; Arístegui et al., 2006, Chavez and Messié, 2009; Meunier et al., 2012). The Mauritanian region within this system is characterized by a relatively wide shelf area, over which upwelled water influences biological productivity (Mittelstaedt, 1991), while extended filaments and island-induced eddies are additional features (Arístegui et al., 2009). The system can be separated into two regimes; the region between 15 and $20^{\circ} \mathrm{N}$ undergoes periodic upwelling which dominates during winter and spring, whereas the region north of $20^{\circ} \mathrm{N}$ is characterized by year-round coastal upwelling with maximum intensity during summer and autumn (Mittelstaedt, 1991). The study region, located between 20 and $22^{\circ} \mathrm{N}$, lies at the confluence of the two source waters upwelled in this system (North At- 
lantic Central Water and South Atlantic Central Water; Mittelstaedt, 1991), which differ in their salinity, temperature, and nutrient characteristics. Nutrient concentrations and potential rates of new production in this region are towards the upper limits of the range reported for global EBUEs (Chavez and Messié, 2009).

The highly dynamic nature of upwelling systems challenges our ability to understand how biological activity develops as water masses advect offshore and what the implications of this activity are for $\mathrm{C}$ export. Both Eulerian (occupying a fixed location over time through which upwelled water passes) and Lagrangian (occupying a water mass as it passes through space and time) strategies have been adopted. The Eulerian approach was successfully applied in a study of the northern Benguela region by Postel et al. (2014); a challenge facing this approach is the risk that stations do not sample successive changes in upwelled water due to the dynamic meandering nature of advective transport. Drifting buoys have been used in previous Lagrangian studies of upwelling regions (Joint et al., 2001b; Wilkerson and Dugdale, 1987) although buoy tracks diverge over time (D'Asaro, 2004), leading to uncertainty about the location of upwelled water masses. To address some of these issues in the present study, the inert gases sulfur hexafluoride $\left(\mathrm{SF}_{6}\right)$ and helium$3\left({ }^{3} \mathrm{He}\right)$ were used to label a water body within a recently upwelled filament (Nightingale et al., 2000). In combination with drifting buoys and mapping exercises, the progression of this labelled water mass and its associated biological activity was followed in Lagrangian mode during offshore advection. Our objective was to investigate phytoplankton productivity and microbial nitrogen cycling and to estimate exportable new production.

The assimilation of nitrogen by phytoplankton was introduced as a means of estimating "new", "regenerated", and "exportable" production ( $f$ ratio; Dugdale and Goering, 1967; Eppley and Peterson, 1979), based on the assumption that $\mathrm{NO}_{3}^{-}$regeneration and assimilation processes were spatially distinct, being associated with the aphotic and photic zones respectively. Consequently, the physical introduction of new nitrogen to the photic zone was deemed capable of supporting an increase in phytoplankton productivity which was available for export. This was readily measured as $\mathrm{NO}_{3}^{-}$ assimilation, though included nitrogen derived from nitrogen fixation. All other forms of nitrogen were deemed to be regenerated, having previously been subject to microbial activity and capable only of sustaining rather than enhancing phytoplankton growth. This was readily measured as $\mathrm{NH}_{4}^{+}$assimilation, though included dissolved organic nitrogen (DON) forms. According to this concept, upwelling regions, which characteristically introduced deep nutrient-rich waters to the photic zone, were associated with high $f$ ratios (i.e. > 0.7) reflecting the high proportion of total nitrogen assimilation supported by $\mathrm{NO}_{3}^{-}$. By contrast, strong stratification in oligotrophic gyres suppressed nutrient inputs to the photic zone, and biological competition for limited nutrient resources maintained very low $\mathrm{NO}_{3}^{-}$concentrations and $f$ ratios (i.e. <0.1).

Following the introduction of the new production paradigm, it has been acknowledged that additional sources and processes related to the biogeochemical cycling of nitrogen are important to new production. Atmospheric inputs of nitrogen in oxidized, reduced, and organic forms are significant for oceanic productivity (Baker et al., 2003; Moore et al., 2013; Powell et al., 2015). The nitrogen inventory of regions such as the North Atlantic is also influenced indirectly by atmospheric inputs, as iron associated with Saharan dust enhances diazotrophic nitrogen fixation, a source of new nitrogen to the surface ocean (Moore et al., 2009; Jickells and Moore, 2015). Although regenerated productivity has often been represented by, and measured as, $\mathrm{NH}_{4}^{+}$assimilation, the significance of DON as a substrate for primary producers has become clearer, including the assimilation of urea and amino acids (Bronk and Glibert, 1993; Bronk and Ward, 1999; Wafar et al., 2004; Moschonas et al., 2015). However, the contribution to total production (i.e. the sum of new and regenerated production) provided by organic forms of nitrogen are rarely considered in $f$ ratio calculations. A related issue is the active release of DON following inorganic nitrogen assimilation; by being released from phytoplankton cells rather than contributing to the formation of new cellular material (i.e. particulate organic nitrogen; PON), this nitrogen is removed from the dissolved inorganic nitrogen pool but is not incorporated into the measured rate of nitrogen assimilation using ${ }^{15} \mathrm{~N}$ techniques (Bronk et al., 1994; Raimbault and Garcia, 2008). Variability in the extent of DON release introduces error in the ${ }^{15} \mathrm{~N}$ budgets of tracer studies.

Error in measured rates of nitrogen assimilation is also introduced by concomitant processes which regenerate nitrogen (Glibert et al., 1982; Kanda et al., 1987). ${ }^{15} \mathrm{NH}_{4}^{+}$isotope dilution due to $\mathrm{NH}_{4}^{+}$regeneration was acknowledged in the new production paradigm, while ${ }^{15} \mathrm{NO}_{3}^{-}$isotope dilution due to nitrification, the sequential oxidation of $\mathrm{NH}_{4}^{+}$to $\mathrm{NO}_{2}^{-}$to $\mathrm{NO}_{3}^{-}$by nitrifying microbes, was assumed to be negligible within the photic zone (Dugdale and Goering, 1967). It has become clear that the process of $\mathrm{NH}_{4}^{+}$regeneration in upwelling systems is highly significant (Raimbault and Garcia, 2008; Clark et al., 2011; Fernández and Farías, 2012; Benavides et al., 2014); while zooplankton excretion and bacterial remineralization are important sources of $\mathrm{NH}_{4}^{+}$, mixotrophic nutrition may be a dominant strategy for the plankton community in upwelling systems, which contribute to $\mathrm{NH}_{4}^{+}$regeneration (Benavides et al., 2014; Mitra et al., 2014). A recently acknowledged role may also exist for the photochemical degradation of DON which regenerates $\mathrm{NH}_{4}^{+}$within the sunlit ocean (Rain-Franco et al., 2014). The combined influence of these processes provides a regenerative $\mathrm{NH}_{4}^{+}$flux which can equal or exceed sink terms, leading to sporadic $\mathrm{NH}_{4}^{+}$accumulation (Fernández and Farías, 2012). Consequently, the influence of $\mathrm{NH}_{4}^{+}$regeneration upon isotope di- 
lution needs to be accounted for in $\mathrm{NH}_{4}^{+}$assimilation rate measurements and subsequent $f$ ratio calculations.

The inhibition of nitrification by light supported the assumption that nitrification was not an important factor in $f$ ratio formulations for the photic zone (Olson, 1981). Although subsequent studies have supported this distribution in nitrifying activity, measurements have demonstrated that $\mathrm{NO}_{3}^{-}$regeneration is significant when compared to concurrent $\mathrm{NO}_{3}^{-}$assimilation in the photic zone (Fernández et al., 2005, 2009; Fernández and Farías, 2012; Clark et al., 2011, 2014). Consequently, although isotope dilution due to the regeneration of $\mathrm{NO}_{3}^{-}$can be accounted for in $\mathrm{NO}_{3}^{-}$assimilation rate calculations, it is implicit that the surface ocean $\mathrm{NO}_{3}^{-}$ pool contains a fraction of regenerated $\mathrm{NO}_{3}^{-}$which cannot readily be measured directly (Martin and Pondaven, 2006).

Conceptually, improving the utility of $f$ ratio measurements would require a full consideration of all new and regenerated forms of inorganic nitrogen to the photic zone which support primary productivity. However, uncertainty about the fraction of photic zone $\mathrm{NO}_{3}^{-}$that truly represents new $\mathrm{NO}_{3}^{-}$is an important and conceptually fundamental limitation that has rarely been acknowledged. Upwelling areas are an exceptional case; seawater upwelled in the Mauritanian system may be regarded as genuinely new to the photic zone, consistent with the original concept. Here we aimed to examine the concept of a transition in $\mathrm{NO}_{3}^{-}$pool provenance from new towards regenerated and to investigate the implications for exportable production estimates in the Mauritanian upwelling system.

\section{Materials and methods}

The study was undertaken on board the RRS Discovery (D338; 15 April to 27 May 2009) as a UK contribution to the international Surface Ocean Lower Atmosphere Study (SOLAS) project. Remotely sensed data were processed by the NERC Earth Observation Data Acquisition and Analysis Service (NEODAAS) at the Plymouth Marine Laboratory (PML) and used to identify a region of active upwelling. Chlorophyll $a$ data were received by NASA from Moderate Resolution Imaging Spectroradiometer (MODIS) and processed using the OC3 chlorophyll algorithm in NASA's SeaViewing Wide Field-of-View Sensor (SeaWiFS) software. Sea-surface temperature data were received by NOAA from an advanced very high-resolution radiometer (AVHRR) and were processed using PML's in-house Panorama processing system (Miller et al., 1997). Upwelling activity was confirmed by hydrographical surveys of water column physical structure involving conductivity-temperature-depth (CTD) rosette casts, Moving Vessel Profiler (MVP; incorporating CTD and fluorescence units) deployments and the use of a shipboard acoustic Doppler current profiler (ADCP; for full details of the mapping exercise, see Meunier et al., 2012). These data were used to select the position for drifter buoy deployment. $\mathrm{SF}_{6} /{ }^{3} \mathrm{He}$ was deployed in a patch (hereafter referred to as $\mathrm{P}_{1}$ ) at a depth of $5 \mathrm{~m}$ around the drifter; full details of the dual tracer technique used during this research program are described in Nightingale et al. (2000). The time interval between receiving satellite data and deploying $\mathrm{SF}_{6} /{ }^{3} \mathrm{He}$ was $<2$ days.

$\mathrm{SF}_{6} /{ }^{3} \mathrm{He}$ was subsequently detected using two ship-based gas chromatography (GC) systems. Seawater samples were collected in discrete mode from depth profiles using CTD rosette-mounted Niskin bottles and continuous mode from the ship's seawater supply collected at approximately $5 \mathrm{~m}$. This analysis identified changes in the horizontal and vertical distribution of $\mathrm{SF}_{6} /{ }^{3} \mathrm{He}$-marked seawater. It ensured that seawater sampling for observational measurements was centred upon the labelled water mass and that the same water mass was sampled until tracer concentrations could no longer be detected reliably, due to the limits of detection associated with GC analysis. Using this approach, chemical, physical, and biological characteristics of the water mass were measured in Lagrangian mode. The duration of the study was 8 days, with sequential sampling days identified by the notation $T_{0}-T_{7}$; pre-patch observations are referred to as $T_{-1}$. One day of sampling was lost due to challenging weather conditions $\left(T_{5}, 28\right.$ April).

For nitrogen regeneration $\left(\mathrm{NH}_{4}^{+}\right.$regeneration, $\mathrm{NH}_{4}^{+}$oxidation, $\mathrm{NO}_{2}^{-}$oxidation) and nitrogen assimilation $\left(\mathrm{NH}_{4}^{+}, \mathrm{NO}_{2}^{-}\right.$, and $\mathrm{NO}_{3}^{-}$) process measurements, seawater samples were collected from CTD rosette-mounted Niskin bottles which sampled routinely at a depth equivalent to $55 \%$ of surface photosynthetically active radiation (SPAR). Additional samples were taken from the $1 \%$ sPAR depth for $\mathrm{NO}_{2}^{-}$oxidation rate measurements only.

The assimilation and regeneration of DIN was investigated using ${ }^{15} \mathrm{~N}$-amended seawater during deck incubations (Clark et al., 2014). Simultaneously, size fractionated primary productivity was measured in depth profiles using deck incubations with ${ }^{14} \mathrm{C}$ (Tilstone et al., 2009). For all deck incubations, neutral density filters simulated SPAR according to Joint Global Ocean Flux Study protocols (Intergovernmental Oceanographic Commission, 1994), and temperature control was achieved by flushing boxes with seawater from the ship's sea-surface supply collected at approximately $5 \mathrm{~m}$.

\subsection{Nitrogen regeneration investigations}

A 24-position stainless-steel rosette system was used to collect seawater from specific depths using 20L Niskin bottles. Water columns were characterized during casts using additional instrumentation attached to the rosette, which included Seabird 9 Plus CTD units, a Seabird SBE 43 dissolvedoxygen sensor and a Chelsea MKIII Aquatracka fluorometer. Seawater was collected during predawn casts (approximately 04:00 GMT) at depths equivalent to specific sPAR values, which were derived from the previous day's light attenuation profiles. All glassware used for the manipulation 
of seawater was cleaned with $10 \% \mathrm{HCl}$ (reagent grade, $37 \%$ ) between CTD sampling iterations and rinsed thoroughly with Milli-Q high-purity water within sampling iterations. Chemicals and solvents were analytical and high-performance liquid chromatography (HPLC) grade, respectively, supplied by Sigma-Aldrich (UK) unless otherwise stated. Stable isotope salts $\left({ }^{15} \mathrm{NH}_{4} \mathrm{Cl}, \mathrm{Na}^{15} \mathrm{NO}_{3}, \mathrm{Na}^{15} \mathrm{NO}_{2}\right)$ were supplied by $\mathrm{CK}$ gas products Ltd (UK).

A $20 \mathrm{~L}$ volume of seawater from each sampling depth was collected in a blacked-out Nalgene container. In the ships laboratory, the preparation of this seawater for incubation studies was also undertaken using blacked-out containers to minimize sample exposure to artificial light sources and the potential disruption of the biological community's natural light-dark cycle. Collected seawater was not pre-filtered (i.e. to remove particles greater than a specific size). As an overview, $6 \mathrm{~L}$ of this seawater was used for nitrogen assimilation studies, while $12 \mathrm{~L}$ was used for nitrogen regeneration studies. Generally, nitrogen regeneration studies were initiated prior to 09:00 GMT and terminated prior to 17:00 GMT providing an average incubation time of $8 \mathrm{~h}$. Within this incubation period, nitrogen assimilation studies were generally initiated by 10:00 GMT and terminated by 16:00 GMT providing an average incubation time of $6 \mathrm{~h}$. Incubations were therefore restricted to daylight hours.

$\mathrm{NH}_{4}^{+}$regeneration rate was determined by amending a $4 \mathrm{~L}$ volume of seawater in a blacked-out container with ${ }^{15} \mathrm{NH}_{4}^{+}$, achieving an average enrichment of $10.7 \pm 8.4 \%{ }^{15} \mathrm{NH}_{4}^{+}$. This volume was thoroughly mixed and left to stand for $20 \mathrm{~min}$ in order to ensure homogeneity. Amended seawater was used to fill a $2.2 \mathrm{~L}$ incubation bottle, which was placed in a deck incubator at simulated light and temperature. The remaining amended seawater was filtered through GF/F glass fibre filters and triplicate $100 \mathrm{~mL}$ volumes were set aside for the determination of pre-incubation $\mathrm{NH}_{4}^{+}$concentration and isotopic enrichment by synthesizing indophenol as described below. Following the deck incubation, bottle contents were filtered through GF/F filters and the filtrate was distributed between $3 \times 100 \mathrm{~mL}$ volumes for the determination of postincubation $\mathrm{NH}_{4}^{+}$concentration and isotopic enrichment by synthesizing indophenol.

A comparable procedure was used for $\mathrm{NH}_{4}^{+}$and $\mathrm{NO}_{2}^{-}$oxidation incubations in which separate $4 \mathrm{~L}$ volumes of seawater were amended with ${ }^{15} \mathrm{NO}_{2}^{-}$and ${ }^{15} \mathrm{NO}_{3}^{-}$, achieving average ${ }^{15} \mathrm{~N}$ enrichments of $8.8 \pm 0.9 \%$ and $9.4 \pm 0.9 \%$ respectively. The concentration and isotopic enrichment of $\mathrm{NO}_{2}^{-}$ was determined by synthesizing sudan- 1 in sample volumes of $100 \mathrm{~mL}$, as described below. The concentration and isotopic enrichment of $\mathrm{NO}_{3}^{-}$was determined by first reducing $\mathrm{NO}_{3}^{-}$to $\mathrm{NO}_{2}^{-}$using a high-capacity cadmium column and then synthesizing sudan- 1 in volumes of $25-50 \mathrm{~mL}$ varying with ambient concentration.

Indophenol was synthesized in samples by adding the first reagent $(4.7 \mathrm{~g}$ phenol and $0.32 \mathrm{~g}$ sodium nitroprusside in $200 \mathrm{~mL}$ Milli $\mathrm{Q}$ water) in the proportion of $1 \mathrm{~mL}$ per $100 \mathrm{~mL}$ of sample volume, mixing the sample and leaving it for $5 \mathrm{~min}$. The second reagent $(1.2 \mathrm{~g}$ sodium dichloroisocyanurate and $2.8 \mathrm{~g}$ sodium hydroxide in $200 \mathrm{~mL}$ Milli Q) was then added in the proportion of $1 \mathrm{~mL}$ per $100 \mathrm{~mL}$ sample volume, mixed and left for $8 \mathrm{~h}$ at room temperature for indophenol development. Indophenol was collected by solidphase extraction (SPE). Sudan-1 was synthesized by adding the first reagent $(0.8 \mathrm{~g}$ of aniline sulfate in $200 \mathrm{~mL} 3 \mathrm{M} \mathrm{HCl})$ to samples in the proportion $0.5 \mathrm{~mL}$ per $100 \mathrm{~mL}$ sample volume. Samples were mixed and left for $5 \mathrm{~min}$ to homogenize, after which sample $\mathrm{pH}$ was verified to be approximately 2.0. Reagent 2 (24 g NaOH and 0.416 g 2-napthol in $200 \mathrm{~mL}$ Milli Q) was added in the proportion $0.5 \mathrm{~mL}$ per $100 \mathrm{~mL}$ sample volume. Samples were again mixed and left for $5 \mathrm{~min}$ before sample $\mathrm{pH}$ was verified to be approximately 8.0. Sudan-1, the development of which was complete after $30 \mathrm{~min}$ of incubation at room temperature, was collected by SPE.

Deuterated internal standards were added to samples immediately prior to SPE collection. Deuterated indophenol and deuterated sudan-1 were synthesized according to methods described previously (Clark et al., 2006, 2007) and purified by HPLC. Standard solutions in methanol were prepared (100 $\mathrm{ng} \mu \mathrm{L}^{-1}$ ) and the concentration verified against analytical standard solutions (Sigma-Aldrich). Appropriate volumes of deuterated internal standards (i.e. comparable to sample size) were added to samples following acidification by citric acid and prior to SPE collection.

Indophenol and sudan-1 were collected by SPE using $6 \mathrm{~mL}$ and $500 \mathrm{mg} \mathrm{C} 18$ cartridges $0.22 \mu \mathrm{m}$ filtered seawater. Prior to sample collection seawater samples were acidified with $1 \mathrm{M}$ citric acid to a $\mathrm{pH}$ of 5.5 before collection by SPE under low vacuum $(120 \mathrm{~mm} \mathrm{Hg})$ at a flow rate of approximately $1 \mathrm{~mL} \min ^{-1}$ without drying. Samples were then rinsed with $5 \mathrm{~mL} 0.22 \mu \mathrm{m}$ filtered seawater and $5 \mathrm{~mL}$ Milli Q water before being air-dried under high vacuum $(360 \mathrm{~mm} \mathrm{Hg}$ ). Samples were stored frozen until further processing at the landbased laboratory.

At the land-based laboratory, samples were brought to room temperature and prepared for HPLC purification and gas chromatography mass spectrometry (GCMS) analysis in the following way. Indophenol samples were eluted from SPE cartridges in $2 \mathrm{~mL}$ methanol. Samples were placed in a bench-top centrifuge for $2 \mathrm{~min}$ at $20000 \times g$ to remove particulate material derived from the SPE column. A $500 \mu \mathrm{L}$ subsample was used for HPLC purification and GCMS analysis, and the remaining $1.5 \mathrm{~mL}$ was stored at $-20^{\circ} \mathrm{C}$ for any subsequent repetition of the analysis. $500 \mu \mathrm{L}$ subsamples were evaporated under oxygen-free nitrogen (OFN) to $200 \mu \mathrm{L}$ for HPLC, during which it was essential that samples were not reduced to dryness. A total of $175 \mu \mathrm{L}$ of the $200 \mu \mathrm{L}$ samples was purified by HPLC using the preparative system, mobile phases, and profile described in Clark et al. (2006) in combination with a Gemini-NX 5u C18 110A $250 \times 4.6 \mathrm{~mm}$ column (Phenomenex, UK) with sample peak collection at a re- 
tention time of $38-40 \mathrm{~min}$. Collected sample fractions were blown dry under OFN at room temperature. Dried samples were stored for $>24 \mathrm{~h}$ over anhydrous silica gel at room temperature prior to GCMS analysis. Samples were derivatized in $50 \mu \mathrm{L}$ of $2.5 \%$ Sylon HT in n-hexane and incubated at $50{ }^{\circ} \mathrm{C}$ for $4 \mathrm{~h}$. Samples were analysed by GCMS using the system, ramping profiles, and extracted ions described in Clark et al. (2006). Internal standards were used to quantify sample $\mathrm{NH}_{4}^{+}$concentration, and when combined with sample enrichment, the rate of $\mathrm{NH}_{4}^{+}$regeneration was determined by applying the Blackburn-Caperon model (Blackburn, 1979; Caperon et al., 1979).

SPE columns loaded with sudan-1 samples were brought to room temperature and processed for HPLC purification and GCMS analysis in the following way. Sudan-1 samples were eluted from SPE cartridges in $2 \mathrm{~mL}$ of ethyl acetate. $100-300 \mu \mathrm{L}$ subsamples were used for further processing, while the remaining samples were stored at $-20^{\circ} \mathrm{C}$ and were available for subsequent repeated analysis. A total of 100$300 \mu \mathrm{L}$ subsamples were blown dry under OFN, redissolved in $200 \mu \mathrm{L}$ methanol, and centrifuged in a bench-top unit at $20000 \times g$ for 2 min to remove particulate material derived from the SPE packing. Samples were transferred to GC vials and purified by HPLC. The HPLC system described in Clark et al. (2007) was used in combination with the Gemini column identified above and the mobile phase profile described in Clark et al. (2014). Sample fractions, which were collected at retention times of 25.5-27.5 min, were dried using a Zymark Turbovap evaporation unit at $50{ }^{\circ} \mathrm{C}$ using OFN. Dried samples were transferred to GC vials and stored over anhydrous silica gel for $24 \mathrm{~h}$ prior to derivatization in a $50 \mu \mathrm{L}$ volume of $2.5 \%$ MTBSTFA in ethyl acetate at $70^{\circ} \mathrm{C}$ for $2 \mathrm{~h}$. The GCMS unit, ramping profile, and extracted ions described in Clark et al. (2007) were used to derive sample $\mathrm{NO}_{2}^{-}$andNO ${ }_{3}^{-}$ concentration and isotopic enrichment. The rate of $\mathrm{NH}_{4}^{+}$or $\mathrm{NO}_{2}^{-}$oxidation was derived by rearranging the mixing model of Sweeney et al. (1978) as described in Clark et al. (2007) and by applying the Blackburn-Caperon model (Blackburn, 1979; Caperon et al., 1979).

\subsection{Nitrogen assimilation measurements and the $f$ ratio}

Using $6 \mathrm{~L}$ of seawater, nitrogen assimilation rates were derived using ${ }^{15} \mathrm{~N}$ techniques. Triplicate $660 \mathrm{~mL}$ volumes of seawater were separately amended with ${ }^{15} \mathrm{NH}_{4}^{+}$and ${ }^{15} \mathrm{NO}_{3}^{-}$ at an enrichment of $7.8 \pm 1.8 \%$ and $8.0 \pm 1.7 \%$ of the ambient concentration respectively. Bottles were placed in deck incubators in conditions of simulated in situ light and temperature. A volume of unamended seawater was filtered through $\mathrm{GF} / \mathrm{F}$ and used to derive the ${ }^{15} \mathrm{~N}$ natural abundance in particulate matter. Deck incubations were terminated by filtration onto $\mathrm{GF} / \mathrm{F}$ filters, which were frozen at $-20^{\circ} \mathrm{C}$ until isotope ratio mass spectrometry analysis was undertaken at the landbased laboratory. The rates of nitrogen assimilation $\left(\rho \mathrm{NH}_{4}^{+}\right.$, $\rho \mathrm{NO}_{3}^{-}$) were determined using the equations of Dugdale and Goering (1967), corrected for nitrogen regeneration using the equations of Kanda et al. (1987).

Nitrogen assimilation data (not corrected for isotope dilution) were used to derive $f$ ratio values by the original formulation as

$f$ ratio $=\frac{\rho \mathrm{NO}_{3}^{-}}{\rho \mathrm{NO}_{3}^{-}+\rho \mathrm{NH}_{4}^{+}}$.

The $f$ ratio was recalculated using nitrogen assimilation rate data corrected for isotope dilution ( $f_{\mathrm{c}}$ ratio). An additional formulation ( $f_{\text {regen }}$ ratio) calculated the $f$ ratio by including a consideration of previously regenerated $\mathrm{NO}_{3}^{-}$within $\mathrm{P}_{1}$, represented as the fraction of the total $\mathrm{NO}_{3}^{-}$pool remaining as new $\mathrm{NO}_{3}^{-}\left(R_{\mathrm{NO}_{3}}\right)$ :

$$
f_{\text {regen }} \text { ratio }=\frac{\left(\rho \mathrm{NO}_{3}^{-} \cdot R_{\mathrm{NO}_{3}}\right)}{\left(\left(\rho \mathrm{NO}_{3}^{-} \cdot R_{\mathrm{NO}_{3}}\right)+\rho \mathrm{NH}_{4}^{+}\right)}
$$

The term $R_{\mathrm{NO}_{3}}$ was calculated using the following procedure and assumptions: it was assumed that $R_{\mathrm{NO}_{3}}$ was conserved (i.e. no mixing took place), that $\mathrm{NO}_{3}^{-}$assimilation was restricted to a $12 \mathrm{~h}$ light phase, that phytoplankton did not differentiate between new and regenerated $\mathrm{NO}_{3}^{-}$, that the measured rate of $\mathrm{NO}_{2}^{-}$oxidation (which regenerates $\mathrm{NO}_{3}^{-}$) was sustained for each $24 \mathrm{~h}$ iteration. As an indication of the utility of using $\mathrm{NO}_{3}^{-}$assimilation and regeneration processes to reflect $\mathrm{NO}_{3}^{-}$pool turnover, a variance of up to $\pm 25 \%$ in calculated compared to measured $\mathrm{NO}_{3}^{-}$pool concentration was measured on a daily basis. However, over the duration of the study $\left(T_{-1}-T_{7}\right)$, this difference was $-0.2 \%$, indicating that changes in ambient $\mathrm{NO}_{3}^{-}$concentration were adequately described by considering only these processes within the constraints stated.

Using $T_{-1}$ as an example, the ambient pool was assumed to have an $R_{\mathrm{NO}_{3}}$ value of 1 , indicating that it was composed of new $\mathrm{NO}_{3}^{-}$only. The amount of $\mathrm{NO}_{3}^{-}$regenerated in this $24 \mathrm{~h}$ period was calculated and added to the ambient concentration. The value of $R_{\mathrm{NO}_{3}}$ after this $24 \mathrm{~h}$ period was calculated by dividing the ambient pool concentration (all new $\mathrm{NO}_{3}^{-}$for this first time point) by the sum of ambient and regenerated $\mathrm{NO}_{3}^{-}$to give a value of 0.94 . For the next $24 \mathrm{~h}$ period $\left(T_{\mathrm{o}}\right)$, the concentration of new $\mathrm{NO}_{3}^{-}$was calculated by multiplying the $T_{0}$ ambient $\mathrm{NO}_{3}^{-}$concentration by the $T_{-1}$ $R_{\mathrm{NO}_{3}}$ value. The $R_{\mathrm{NO}_{3}}$ value at the end of this $24 \mathrm{~h}$ period was calculated by dividing the concentration of new $\mathrm{NO}_{3}^{-}$by the sum of ambient and newly regenerated (i.e. within $T_{0}$ ) $\mathrm{NO}_{3}^{-}$to provide a value of 0.81 . This process was repeated for the study period. 


\subsection{Primary productivity measurements}

Phytoplankton productivity was measured using the ${ }^{14} \mathrm{C}$ method (Tilstone et al., 2009). Samples were collected predawn from five depths $(97,55,33,14,1 \%$ sPAR). Triplicate $75 \mathrm{~mL}$ subsamples were amended with between 185 and $740 \mathrm{kBq}(5-20 \mu \mathrm{Ci}) \mathrm{NaH}^{14} \mathrm{CO}_{3}$ and incubated on-deck for $24 \mathrm{~h}$ at simulated sPAR depth. Incubations were terminated by sequential filtration through 2 and $0.2 \mu \mathrm{m}$ polycarbonate filters. ${ }^{14} \mathrm{C}$ disintegration was measured on-board using a TriCarb liquid scintillation counter.

\subsection{Chlorophyll concentration}

Chlorophyll $a$ samples were collected simultaneously with seawater used for primary productivity measurements; $250 \mathrm{~mL}$ subsamples were collected from five depths $(97,55$, $33,14,1 \%$ sPAR) from predawn CTD casts and immediately filtered sequentially through 2 and $0.2 \mu \mathrm{m}$ polycarbonate filters. Filters were soaked in $10 \mathrm{~mL} 90 \%$ acetone for $12 \mathrm{~h}$ and extracts analysed fluorometrically using a Trilogy Turner fluorometer calibrated against pure chlorophyll $a$ standards (Sigma).

\subsection{Microscopy}

Seawater samples were collected from five depths $(97,55$, 33, 14, 1\% sPAR) during predawn CTD casts. Samples were immediately fixed in acid Lugol's iodine solution (2\% final concentration). Where possible, cells were identified to species level according to the published literature and assigned to three functional groups (diatoms (centric \& pennate), dinoflagellates, flagellates). Cells were enumerated and expressed as cells per millilitre.

\subsection{Inorganic nutrients}

Seawater samples were collected from a range of depths during predawn CTD casts into cleaned, acid-washed, and "aged" high-density polyethylene sample bottles, using clean handling and analysis procedures. Samples were analysed immediately. Nitrate, nitrite, ammonium, phosphate, and silicate were measured colorimetrically with a five-channel segmented flow Bran and Luebbe AAIII autoanalyser, using methods described previously (Woodward and Rees, 2001).

\section{Results and discussion}

The inert dual tracers $\mathrm{SF}_{6}$ and ${ }^{3} \mathrm{He}$ (Nightingale et al., 2000) in combination with drifter buoys were used in this study so that filament progression and biological community development could be followed in Lagrangian mode as the water mass advected offshore (Fig. 1). The loss of tracers to the atmosphere, their dilution due to mixing with unlabelled water, and the detection limit of GC analysis constrained patch
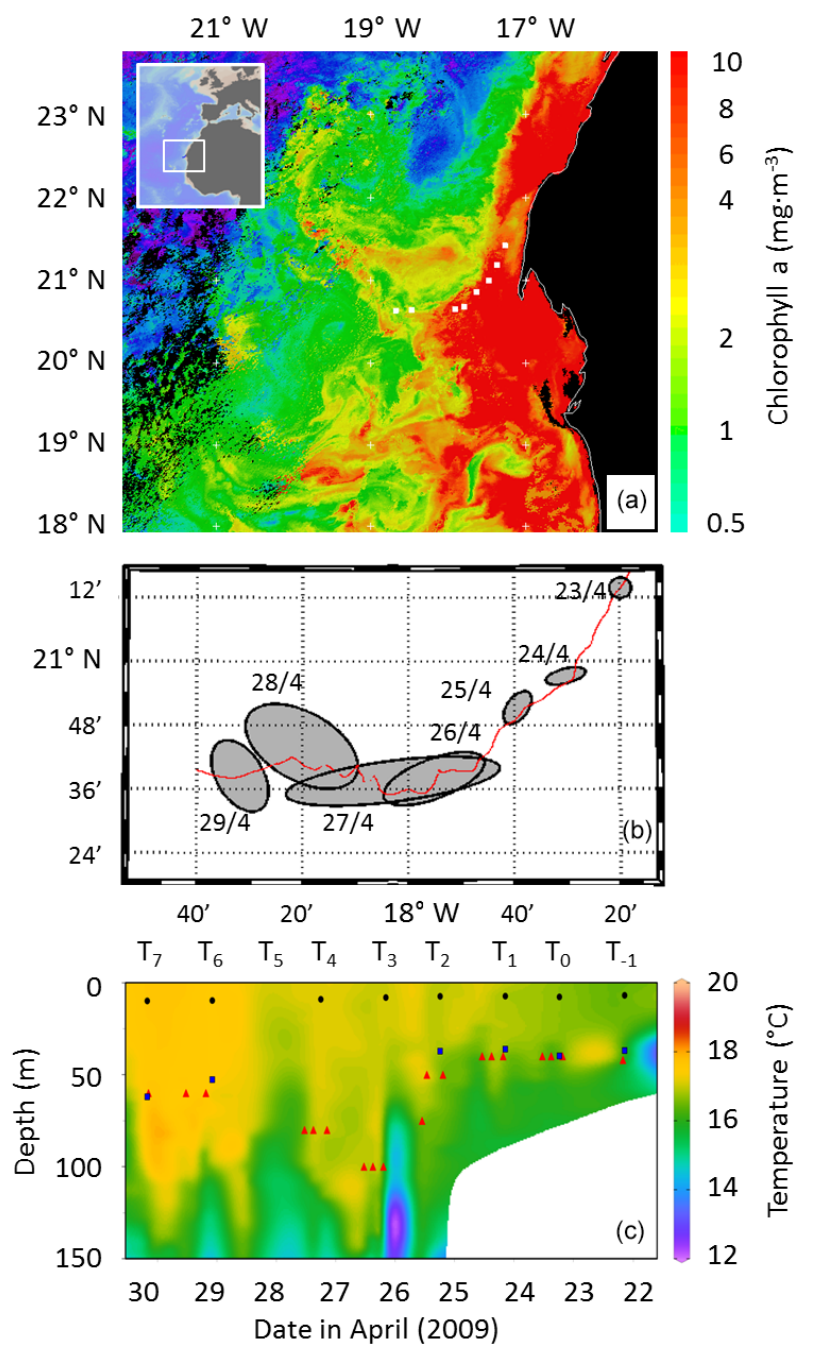

Figure 1. Panel (a) presents composite sea-surface chlorophyll $a$ (20-30 April 2009) of the sampling area. The station locations are identified as white squares. Panel (b) presents the daily lateral $\mathrm{SF}_{6} /{ }^{3} \mathrm{He}$ distribution, defined as $40 \%$ of the peak concentration. The red line indicates the track of a central marker buoy used in combination with $\mathrm{SF}_{6} /{ }^{3} \mathrm{He}$ analysis. Panel (c) presents water column temperature $\left({ }^{\circ} \mathrm{C}\right)$ and includes sampling depths for $55 \% \mathrm{sPAR}$ (black circles) and $1 \%$ sPAR (blue squares). The depth of the upper mixed layer is indicated (red triangles; Loucaides et al., 2012). Note the reversal of dates in (c) to aid comparisons between figures.

monitoring duration. A detailed description of filament dynamics forming off Cap Blanc during this study is presented in Meunier et al. (2012). Both North and South Atlantic Central Water (NACW and SACW respectively) is upwelled in this region and the contribution to filaments from each source can be distinguished; SACW generally contains higher nutrient concentrations and has higher temperature with lower oxygen and salinity. Optimum parameter analysis (Rees et al., 2011) demonstrated that the filament studied was dominated by NACW (50-80\%). 

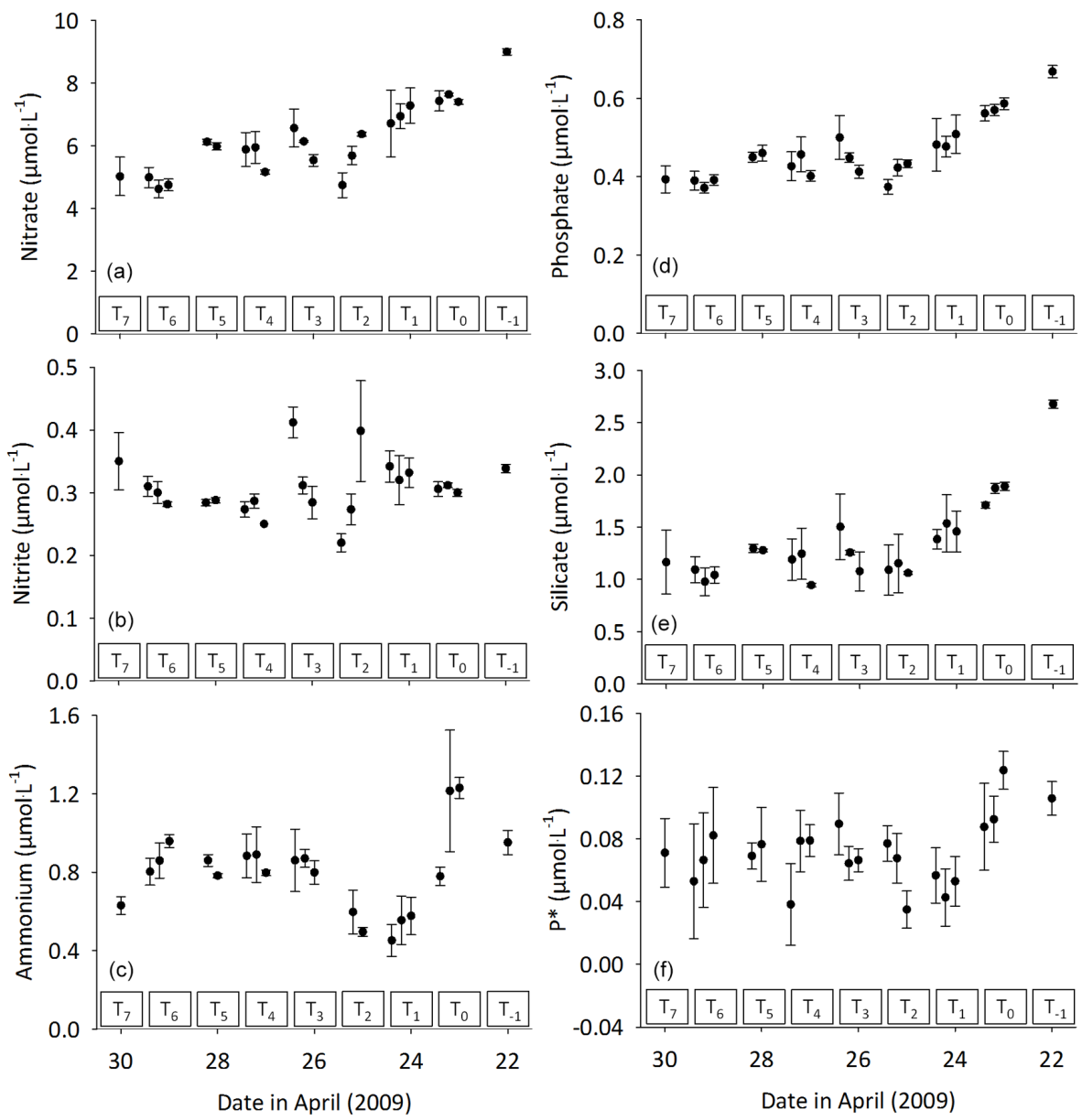

Figure 2. Average concentration of inorganic nutrients within the upper mixed layer: (a) nitrate, (b) nitrite, (c) ammonium, (d) phosphate, (e) silicate. The phosphate excess $\left(\mathrm{P}^{*}\right)$ is presented in panel (f). Error bars represent 1 standard deviation for triplicate concentration measurements. Note the reversal of dates to aid comparisons between figures.

$\mathrm{P}_{1}$ was identified using a combination of near-real time remotely sensed data and water column profiling. Following identification, observational measurements were undertaken and $\mathrm{SF}_{6} /{ }^{3} \mathrm{He}$ tracers were deployed at a depth of $5 \mathrm{~m}$ in a square spiral $(1.0 \times 0.8 \mathrm{~km})$ around a central drifting buoy. Tracers were detected throughout the surface mixed layer depth (MLD) of $50 \mathrm{~m}$ within 1 day of deployment. Extensive mapping exercises were conducted to describe $\mathrm{P}_{1}$ 's progression as the water mass advected offshore in a south-westerly then westerly direction. Mapping enabled the patch centre to be located for daily observational measurements. During this study, $\mathrm{P}_{1}$ remained tightly constrained for the first 3 days until the patch left the continental shelf area and entered the upper slope and shelf break regions. During this latter stage enhanced vertical mixing due to increased water column depth combined with horizontal sheer associated with patch proximity to the northern edge of the filament led to $\mathrm{P}_{1}$ elongation and dispersion.

\subsection{Description of the physical and chemical regime}

Selected chemical, biological, and physical characteristics of the water column are presented in Figs. 1-4. As $P_{1}$ advected offshore, its temperature increased from approximately $16.4{ }^{\circ} \mathrm{C}$ on $T_{-1}$ to $>17.6^{\circ} \mathrm{C}$ by $T_{7}$ (Fig. 1). Profiles of water column temperature demonstrated changes in vertical structure as the mixed layer depth increased from approximately $50 \mathrm{~m}\left(T_{-1}-T_{2}\right)$ to $100 \mathrm{~m}$ coinciding with the continental shelf to shelf break transition $\left(T_{3}\right.$; Loucaides et al., 2012). Nutrient concentrations in $P_{1}$ were greatest during the first day of Lagrangian study and then progressively decreased (with the exception of $\mathrm{NO}_{2}^{-}$; Fig. 2). On average, $\mathrm{NO}_{3}^{-}$concentration decreased from $9.0 \pm 0.1 \mu \mathrm{mol} \mathrm{L}-1$ to $4.6 \pm 0.3 \mu \mathrm{mol} \mathrm{L}{ }^{-1}$, Si concentration decreased from $2.7 \pm$ $0.1 \mu \mathrm{mol} \mathrm{L}-1$ to $0.9 \pm 0.1 \mu \mathrm{mol} \mathrm{L}-1$, and $\mathrm{PO}_{4}^{3-}$ concentration decreased from $0.7 \pm 0.1 \mu \mathrm{mol} \mathrm{L}^{-1}$ to $0.4 \pm 0.1 \mu \mathrm{mol} \mathrm{L}{ }^{-1}$. The greatest decrease in nutrient concentrations occurred on the continental shelf. Following advection over the shelf break, these nutrient concentrations continued to decrease 

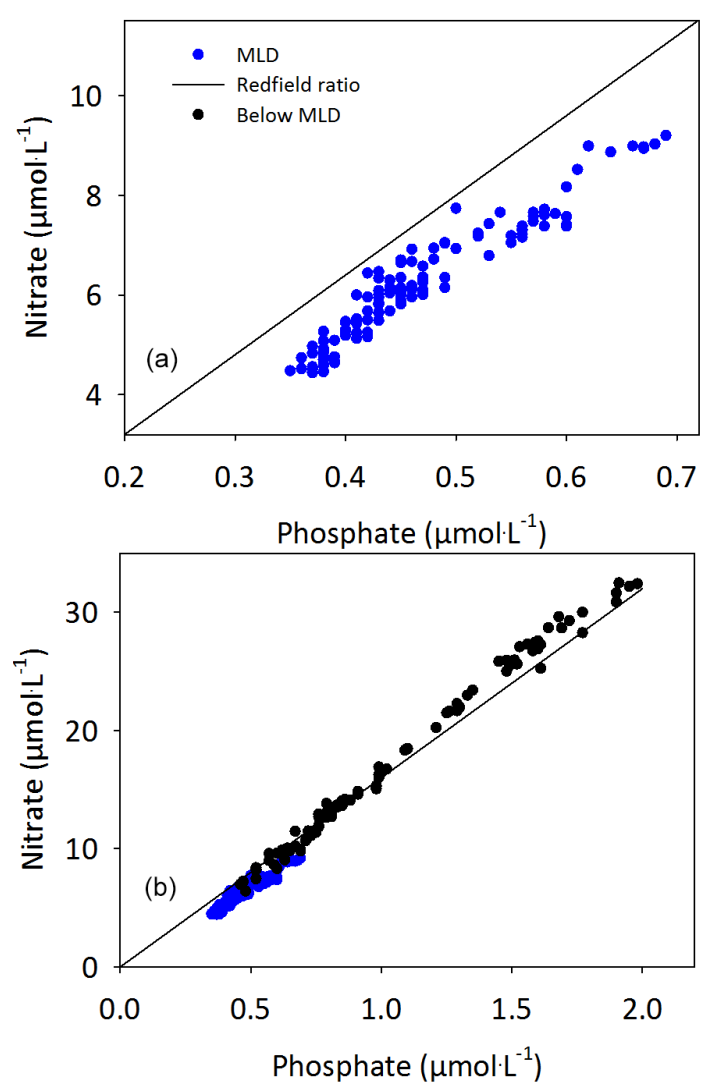

Figure 3. Ratio between ambient concentrations of nitrate and phosphate. The solid regression line is the Redfield ratio of $16: 1$. Data from within the surface mixed layer depth (MLD) are presented in (a), the regression of which provides a ratio of 13.9:1 and a phosphate excess of $72 \pm 18 \mathrm{nmol} \mathrm{PL}^{-1}$. Data from below the MLD, presented in (b), were collected to a maximum depth of $1.4 \mathrm{~km}$. The regression of this data provided a ratio of $17.7: 1$.

albeit at a lower rate. By contrast, $\mathrm{NO}_{2}^{-}$concentration remained relatively stable for the duration of the study at $0.31 \pm 0.05 \mu \mathrm{mol} \mathrm{L}{ }^{-1}$, while a simple increasing or decreasing trend in $\mathrm{NH}_{4}^{+}$concentration was not evident; an average value of $0.8 \pm 0.23 \mu \mathrm{mol} \mathrm{L}^{-1}$ was measured.

Nutrient stoichiometry of the upwelled $\mathrm{P}_{1}$ water mass (i.e. within the upper mixed layer) indicated nitrogen deficiency (Fig. 3); regression provided a N : $\mathrm{P}$ value of $13.9: 1 \mathrm{com}-$ pared to a value of $17.7: 1$ below the mixed layer (incorporating depths up to $1400 \mathrm{~m}$ ). This value for the photic zone is consistent with the range of 10-16 reported for freshly upwelled coastal waters by Zindler et al. (2012) in their study of the Mauritanian upwelling. The difference in $\mathrm{N}: \mathrm{P}$ values between depths, i.e. for $\mathrm{P}_{1}$ within the upper mixed layer compared to depths below this, is likely to reflect the relatively rapid biological consumption of $\mathrm{N}$ relative to $\mathrm{P}$ within the photic zone (Zindler et al., 2012). In contrast, the Namibian shelf's mud belt is a region of continuous $\mathrm{N}$ loss and $\mathrm{P}$ efflux to the pelagic environment of the Benguela upwelling system, leading to characteristically low $\mathrm{N}: \mathrm{P}$ ratios. Gregor and Monteiro (2013), who reported pelagic N : P values of $7.2-12.3$, identified denitrification and sulfate reduction as anoxic benthic processes leading to this relative nitrogen deficiency, a finding supported by Flohr et al. (2014).

The relative nitrogen deficiency measured in $\mathrm{P}_{1}$ implied a relative $\mathrm{P}$ excess $\left(\mathrm{P}^{*}\right.$, calculated as $\left.\left[\mathrm{PO}_{4}^{3-}\right]-\left(\left[\mathrm{NO}_{3}^{-}\right] / 16\right)\right)$. An average $\mathrm{P}^{*}$ of $72 \pm 18 \mathrm{nmol} \mathrm{L}^{-1}$ (Figs. 2f and 3) indicated that $\mathrm{P}_{1}$ exported phosphate to the adjacent oligotrophic gyre of the North Atlantic. The magnitude of this export was less than the value of approximately $300 \mathrm{nmol} \mathrm{L}^{-1}$ reported for phosphate advection to the South Atlantic gyre by the Benguela upwelling system (Flohr et al., 2014). A P* decline towards zero would be anticipated with offshore advection due to nitrogen fixation, supported by atmosphericdust-associated iron inputs to the North Atlantic derived from the Sahara region. Dust inputs mitigate the enhanced iron requirements of nitrogen-fixing diazotrophs (Moore et al., 2009), ultimately providing a new nitrogen source to the North Atlantic Ocean (Deutsch et al., 2007). In their study of the Benguela upwelling region, Sohm et al. (2011) suggested that environmental conditions influencing nitrogen fixation are poorly understood and that nitrogen-fixing activity extends beyond the tropical and subtropical low-nutrient regions characteristically considered, also including cool, high-nutrient regions. They reported nitrogen fixation rates approaching $8 \mathrm{nmol} \mathrm{L}^{-1} \mathrm{~d}^{-1}$, potentially supported by sedimentary sources of iron during a period of low atmospheric dust input. In contrast, undetectable or low rates of nitrogen fixation $\left(<1 \mathrm{nmol} \mathrm{L}^{-1} \mathrm{~d}^{-1}\right)$ in the Benguela have been reported to make an insignificant contribution to new production (Staal et al., 2007; Benavides et al., 2014; Wasmund et al., 2015). A comparable conclusion for freshly upwelled water was reached during the present study as nitrogen fixation rates in $\mathrm{P}_{1}$ were undetectable (Rees, unpublished data).

Analysis demonstrated that nutrient drawdown during $\mathrm{P}_{1}$ progression was driven by biological processes (Loucaides et al., 2012); factors such as horizontal and vertical mixing with low-nutrient water masses derived from outside of the upwelled filament were unlikely to have made a significant contribution. However, an entrainment event associated with increased mixed layer depth lead to a small but measurable recovery in nutrient concentrations during $T_{3}-T_{4}$.

Nutrient drawdown supported high rates of primary production (Fig. 4). Rates were measured within the range 0.1$0.7 \mathrm{~mol} \mathrm{C} \mathrm{m}^{-2} \mathrm{~d}^{-1}$, which sets an upper limit for $\mathrm{C}$ export through a combination of particulate material sedimentation (Nowald et al., 2015), lateral transport of dissolved organic matter (Álvarez-Salgado et al., 2007), and trophic transfer. The range in primary productivity was comparable to the value of $0.2 \mathrm{~mol} \mathrm{C} \mathrm{m}^{-2} \mathrm{~d}^{-1}$ reported for the region by Minas et al. (1986) and potentially exceeds that measured in other upwelling areas; values of $0.02-0.21 \mathrm{~mol} \mathrm{C} \mathrm{m}^{-2} \mathrm{~d}^{-1}$ were reported for the Iberian upwelling (Joint et al., 2001a; 


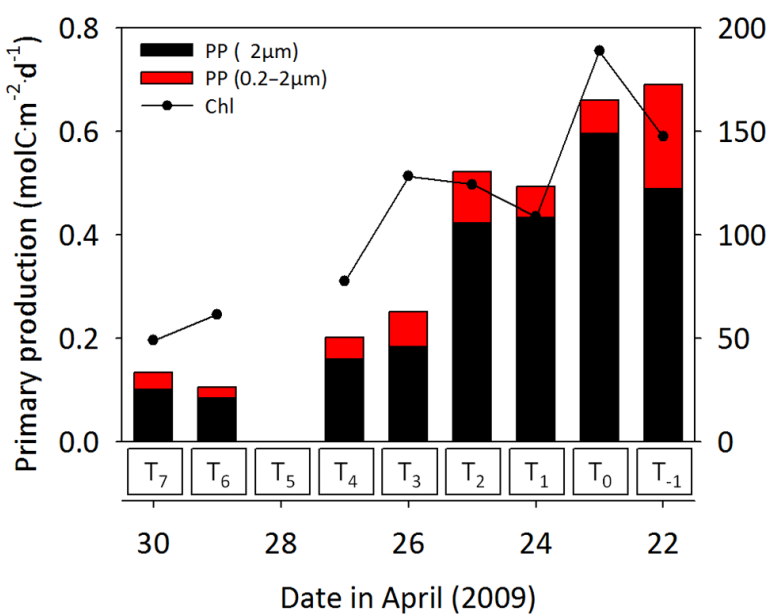

Figure 4. Changes in integrated (photic depth) primary production and integrated chlorophyll concentration in two size fractions (> $2 \mu \mathrm{m}$ and $0.2-2 \mu \mathrm{m}$ ). Note the reversal of dates to aid comparisons between figures.

Álvarez-Salgado et al., 2002; Arístegui et al., 2006), 0.01$0.46 \mathrm{~mol} \mathrm{C} \mathrm{m}^{-2} \mathrm{~d}^{-1}$ was reported for the Peruvian upwelling (Fernández et al., 2009), an average of $0.23 \mathrm{~mol} \mathrm{C} \mathrm{m}^{-2} \mathrm{~d}^{-1}$ was reported for the southern Benguela region (Shannon and Field, 1985), and $0.07 \mathrm{~mol} \mathrm{C} \mathrm{m}^{-2} \mathrm{~d}^{-1}$ was reported for the Californian upwelling ecosystem (Santoro et al., 2010).

In terms of distribution, the highest rates of primary productivity were associated with the continental shelf region (0.49-0.69 mol $\left.\mathrm{C} \mathrm{m}^{-2} \mathrm{~d}^{-1}\right)$, with rates decreasing as $\mathrm{P}_{1}$ advected over the shelf break $\left(0.11-0.25 \mathrm{~mol} \mathrm{C} \mathrm{m}^{-2} \mathrm{~d}^{-1}\right)$. This distribution was characteristic of the coastal north-west African region, with high biological productivity associated with the continental shelf area influenced by upwelling (Mittelstaedt, 1991; Arístegui et al., 2009).

\subsection{Phytoplankton composition and nitrogen assimilation}

Freshly upwelled water is extremely low in chlorophyll content and productivity and would characteristically contain a $\mathrm{NO}_{3}^{-}$concentration in the range $9-15 \mu \mathrm{mol} \mathrm{L}^{-1}$ for this region (Arístegui et al., 2009, noting that $\mathrm{P}_{1}$ 's composition of NACW and SACW would place freshly upwelled water towards the upper end of this range). Consequently, productivity had become established and decreased $\mathrm{NO}_{3}^{-}$by up to $6 \mu \mathrm{mol} \mathrm{L} \mathrm{L}^{-1}$ prior to this study, which followed the removal of a further $4 \mu \mathrm{mol} \mathrm{L}{ }^{-1}$ of $\mathrm{NO}_{3}^{-}$. During $\mathrm{P}_{1}$ progression, clear transitions in phytoplankton abundance, nitrogen biomass, and nitrogen assimilation activity took place (Fig. 5). The highest abundance of all phytoplankton was measured during the first 3 days of the Lagrangian study $\left(T_{0}-T_{2}\right)$. Although flagellates were numerically dominant, diatoms dominated carbon biomass, representing between 40 and $80 \%$ (data not shown). Cell abundance decreased beyond $T_{2}$ although spe-
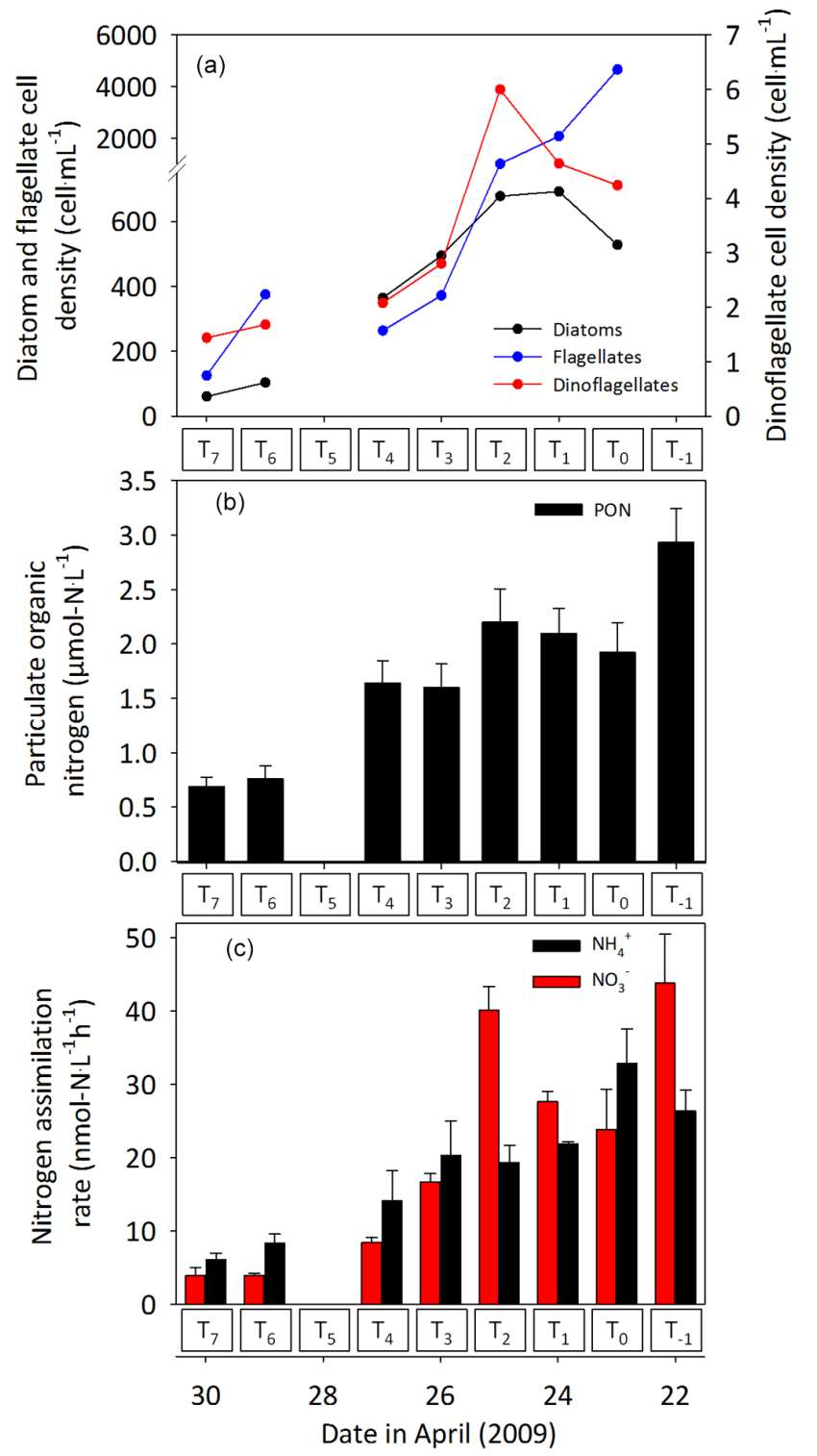

Figure 5. Changes in the abundance of phytoplankton (a), the concentration of particulate organic nitrogen (PON, b), and the rate of nitrogen assimilation as nitrate and ammonium (c). PON and nitrogen assimilation were measured within the mixed layer at $55 \%$ sPAR. Error bars represent 1 standard deviation for triplicate concentration (b) or rate (c) measurements. Note the reversal of dates to aid comparisons between figures.

cific phytoplankton classes represented a consistent proportion of total abundance, suggesting that selective removal was not an important factor; for the duration of this study, diatoms represented $12.7 \pm 5.7 \%$, dinoflagellates represented $0.10 \pm 0.02 \%$, and flagellates represented $87.2 \pm 5.7 \%$ of total cell abundance. The trend of progressively diminishing phytoplankton abundance was reflected in the concentration of PON, which decreased by $75 \%$ within 8 days. 
During this study, $\mathrm{NH}_{4}^{+}$assimilation was measured within the range $6.1-32.8 \mathrm{nmol} \mathrm{L}^{-1} \mathrm{~h}^{-1}$, while $\mathrm{NO}_{3}^{-}$assimilation was measured within the range $3.9-43.8 \mathrm{nmol} \mathrm{L}^{-1} \mathrm{~h}^{-1}$. There are relatively few studies of nitrogen assimilation in the north-west African region against which to draw comparisons; $\mathrm{NO}_{3}^{-}$assimilation measured within the photic zone was previously reported in the range $<0.2-31 \mathrm{nmol} \mathrm{L}^{-1} \mathrm{~h}^{-1}$ (Varela et al., 2005; Dugdale et al., 1990), while $\mathrm{NH}_{4}^{+}$assimilation was reported in the range $<0.2-105 \mathrm{nmol} \mathrm{L}^{-1} \mathrm{~h}^{-1}$ (Varela et al., 2005; Benavides et al., 2013). The fact that rates of $\mathrm{NH}_{4}^{+}$and $\mathrm{NO}_{3}^{-}$assimilation were broadly similar for $\mathrm{P}_{1}$ despite the difference in nitrogen source availability was perhaps the most striking observation. The average $\mathrm{P}_{1} \mathrm{NH}_{4}^{+}$and $\mathrm{NO}_{3}^{-}$concentrations were $0.80 \pm 0.23$ and $6.22 \pm 1.20 \mu \mathrm{mol} \mathrm{L}{ }^{-1}$ respectively, differing by almost 1 order of magnitude. Results underscore the importance of regenerated nitrogen in supporting phytoplankton nitrogen requirements even from the early stages of upwelling and imply that this form of inorganic nitrogen was rapidly recycled. The significance of nitrogen regeneration in upwelling regions has previously been highlighted (Raimbault and Garcia, 2008; Clark et al., 2011; Fernández and Farías, 2012; Benavides et al., 2014).

Within the conveyor belt scheme describing productivity cycles in upwelling systems (Wilkerson and Dugdale, 2008), the increase in phytoplankton growth in response to favourable light and nutrient conditions (shift-up phase) is followed by a shift-down phase driven by factors such as sedimentation and grazing. Cycles last between 5 and 7 days. The trend of progressively diminishing indicators of phytoplankton abundance and activity in combination with a calculated residence time within the photic zone of 3 days for upwelled water prior to $T_{\mathrm{o}}$ (Meunier et al., 2012; Loucaides et al., 2012) suggested that the peak and shift-down stages of phytoplankton productivity were investigated here. Contributory factors (excluding sedimentation and grazing for which we have no data) to the shift-down phase are discussed below.

In previous studies of upwelling regimes, inorganic nutrient availability has been identified as a limiting resource driving changes in community structure and productivity (Wilkerson and Dugdale, 2008). Nutrient limitation of larger cells, which dominated productivity in the present study, may have been a contributory factor. For example, the average $\mathrm{N}: \mathrm{Si}$ ratio for the duration of $\mathrm{P}_{1}(4.49 \pm 0.78)$ indicated potential silicate limitation of diatom growth (Brzezinski, 1985; Gilpin et al., 2004). However, relatively high-nutrient concentrations were detected by $T_{7}$ and a shift in community structure was not observed; the comparable decrease in cell abundance across all phytoplankton classes implied a less specific driver behind the decrease in biomass during the relatively short duration of this investigation.

Light may be considered as a limiting resource; profiles of light intensity and optical depth diminish during the pro- lific growth of phytoplankton in surface waters; average daily light exposure for cells will also diminish during water column structure transitions as observed beyond $T_{2}$ where MLD exceeded the $1 \%$ sPAR depth. Under these circumstances, light limitation would be expressed as a preferential use of $\mathrm{NH}_{4}^{+}$over $\mathrm{NO}_{3}^{-}$due to the differential energetic demands (Clark et al., 2002; Flynn et al., 2002). This was not observed during $T_{-1}-T_{2}$. However, $\mathrm{NH}_{4}^{+}$assimilation rate consistently exceeded $\mathrm{NO}_{3}^{-}$assimilation beyond $T_{3}$ (the point at which MLD exceeded the $1 \%$ sPAR depth), potentially supporting this mechanism to describe a characteristic feature of nitrogen assimilation by phytoplankton in upwelled water (Dickson and Wheeler, 1995; Kudela et al., 1997) and contributing to the progressive decrease in indicators of phytoplankton activity and biomass.

\subsection{The regeneration of inorganic nitrogen}

The evidence presented here demonstrates that the regeneration of inorganic nitrogen sustained phytoplankton productivity during $\mathrm{P}_{1}$ development. Nutrient regeneration is a product of heterotrophic dissolved organic matter (DOM) degradation by microplankton (bacteria, flagellates, ciliates), following its release from phytoplankton due to grazing (Probyn, 1987; Varela et al., 2003; Bode et al., 2004) or its active release from phytoplankton during nutrient assimilation (Bronk et al., 1994; Raimbault and Garcia, 2008; Benavides et al., 2013). Alternative routes of $\mathrm{NH}_{4}^{+}$regeneration in upwelling systems may be minor (e.g. the activity of zooplankton; Bode et al., 2004; Bronk and Steinberg, 2008; Fernández-Urruzola et al., 2014) or difficult to quantify, such as the contribution from the photochemical degradation of DON (Rain-Franco et al., 2014).

During the present study, $\mathrm{NH}_{4}^{+}$was regenerated at rates within the range 9.4-85.0 $\mathrm{nmol} \mathrm{L}^{-1} \mathrm{~h}^{-1}$ (Fig. 6). We are unaware of previous studies for the Mauritanian system with which to compare this data. For Cape Ghir (north of the study location), Benavides et al. (2013) reported $\mathrm{NH}_{4}^{+}$regeneration rates of $8 \mathrm{nmol} \mathrm{L}^{-1} \mathrm{~h}^{-1}$. For the Benguela system Probyn $(1987,1990)$ reported rates of $0-125 \mathrm{nmol} \mathrm{L}^{-1} \mathrm{~h}^{-1}$ and Benavides et al. (2014) reported rates of $90-130 \mathrm{nmol} \mathrm{L}^{-1} \mathrm{~h}^{-1}$. For the less productive Iberian upwelling system, rates of 0.09-2.52 $\mathrm{nmol} \mathrm{L}^{-1} \mathrm{~h}^{-1}$ have been reported (Clark et al., 2011). Benavides et al. (2013) speculated in their study of the Benguela system that high rates of $\mathrm{NH}_{4}^{+}$regeneration were driven by a high abundance of dinoflagellates and mixotrophic microflagellates. In the present study, the highest rate of $\mathrm{NH}_{4}^{+}$regeneration was measured at $T_{0}$, coinciding with the highest ambient ammonium concentration and abundance of phytoplankton, notably flagellates. This offered circumstantial evidence supporting a role for microflagellates in $\mathrm{NH}_{4}^{+}$regeneration (Benavides et al., 2013). Conversely, bacterial abundance derived from analytical flow cytometry (data not shown) did not offer any clear or statistically significant link with measured rates of $\mathrm{NH}_{4}^{+}$regeneration sug- 
gesting that this route may have been of minor importance. Considering all data, an $\mathrm{NH}_{4}^{+}$pool turnover of $1.2 \pm 0.7 \mathrm{~d}^{-1}$ due to regeneration and a ratio of $1.7 \pm 1.1$ for $\mathrm{NH}_{4}^{+}$regeneration to assimilation rate demonstrated the rapidity of $\mathrm{NH}_{4}^{+}$ recycling that was sufficient to meet phytoplankton requirements, as also reported for other upwelling systems (Benavides et al., 2013, 2014; Raimbault and Garcia, 2008; Clark et al., 2011; Fernández and Farías, 2012).

A sink for regenerated $\mathrm{NH}_{4}^{+}$is the nitrification process. The sequential oxidation of $\mathrm{NH}_{4}^{+}$to $\mathrm{NO}_{2}^{-}$and $\mathrm{NO}_{3}^{-}$is known not to be restricted to aphotic depths (Raimbault and Garcia, 2008; Clark et al., 2008, 2014) and has been reported in other upwelling systems (Clark et al., 2011; Fernández and Farías, 2012; Benavides et al., 2014). In their study of the Chilean upwelling system, Fernández and Farías (2012) demonstrated that oxygen concentrations have an important influence over nitrogen cycle processes, influencing the vertical distribution of nitrifying microorganisms. In oxic photic zone conditions comparable to $\mathrm{P}_{1}$, these authors suggested that Crenarchaeota rather than bacteria dominate nitrifying activity.

During the present study, $20 \pm 10 \%$ of regenerated $\mathrm{NH}_{4}^{+}$entered the nitrification pathway. Rates of $\mathrm{NH}_{4}^{+}$and $\mathrm{NO}_{2}^{-}$oxidation were $0.30-8.75 \mathrm{nmol} \mathrm{L}^{-1} \mathrm{~h}^{-1}$ and 25.55 $81.11 \mathrm{nmol} \mathrm{L}^{-1} \mathrm{~h}^{-1}$ respectively, resulting in an average turnover of $0.3 \pm 0.2$ and $0.2 \pm 0.1 \mathrm{~d}^{-1}$ for $\mathrm{NO}_{2}^{-}$and $\mathrm{NO}_{3}^{-}$ respectively. We are unaware of previous nitrification rate measurements for the Mauritanian system and as a general observation such measurements are rare for upwelling systems. For the Benguela system, $\mathrm{NO}_{3}^{-}$regeneration rates of $0.6-15.5 \mathrm{nmol} \mathrm{L}^{-1} \mathrm{~h}^{-1}$ have been reported (Füssel et al., 2011; Benavides et al., 2014) although in Cape Ghir nitrification was not detected (Benavides et al., 2013). In the Iberian system, Clark et al. (2011) reported rates of 0.06$3.74 \mathrm{nmol} \mathrm{L}^{-1} \mathrm{~h}^{-1}$ and $0.04-24.76 \mathrm{nmol} \mathrm{L}^{-1} \mathrm{~h}^{-1}$ for $\mathrm{NH}_{4}^{+}$ and $\mathrm{NO}_{2}^{-}$oxidation respectively.

The average coupling ratio $\left(\mathrm{NH}_{4}^{+}: \mathrm{NO}_{2}^{-}\right.$oxidation rate) was $0.11 \pm 0.07$, indicating that these processes were substantively uncoupled; the $\mathrm{NO}_{2}^{-}$oxidation rate exceeded the $\mathrm{NH}_{4}^{+}$oxidation rate by several times as previously reported (Lipschultz et al., 1990; Beman et al., 2010, 2013; Clark et al., 2011, 2014; Füssel et al., 2011; Fernández and Farías, 2012; Ganesh et al., 2015). The extent of decoupling would imply that $\mathrm{NO}_{2}^{-}$oxidation was unsustainable, as $\mathrm{NO}_{2}^{-}$would be removed within 1 day at the prevailing $\mathrm{NO}_{2}^{-}$oxidation rates. However, a $\mathrm{NO}_{2}^{-}$concentration of approximately $0.3 \mu \mathrm{mol} \mathrm{L}{ }^{-1}$ persisted in the photic zone for the duration of the study indicating an approximate balance between $\mathrm{NO}_{2}^{-}$ production and consumption processes. Füssel et al. (2011) suggested that in suboxic environments associated with the Namibian oxygen minimum zone, $\mathrm{NO}_{2}^{-}$produced via $\mathrm{NO}_{3}^{-}$ reduction (the first stage of denitrification) could, in combination with $\mathrm{NH}_{4}^{+}$oxidation, support the observed rates

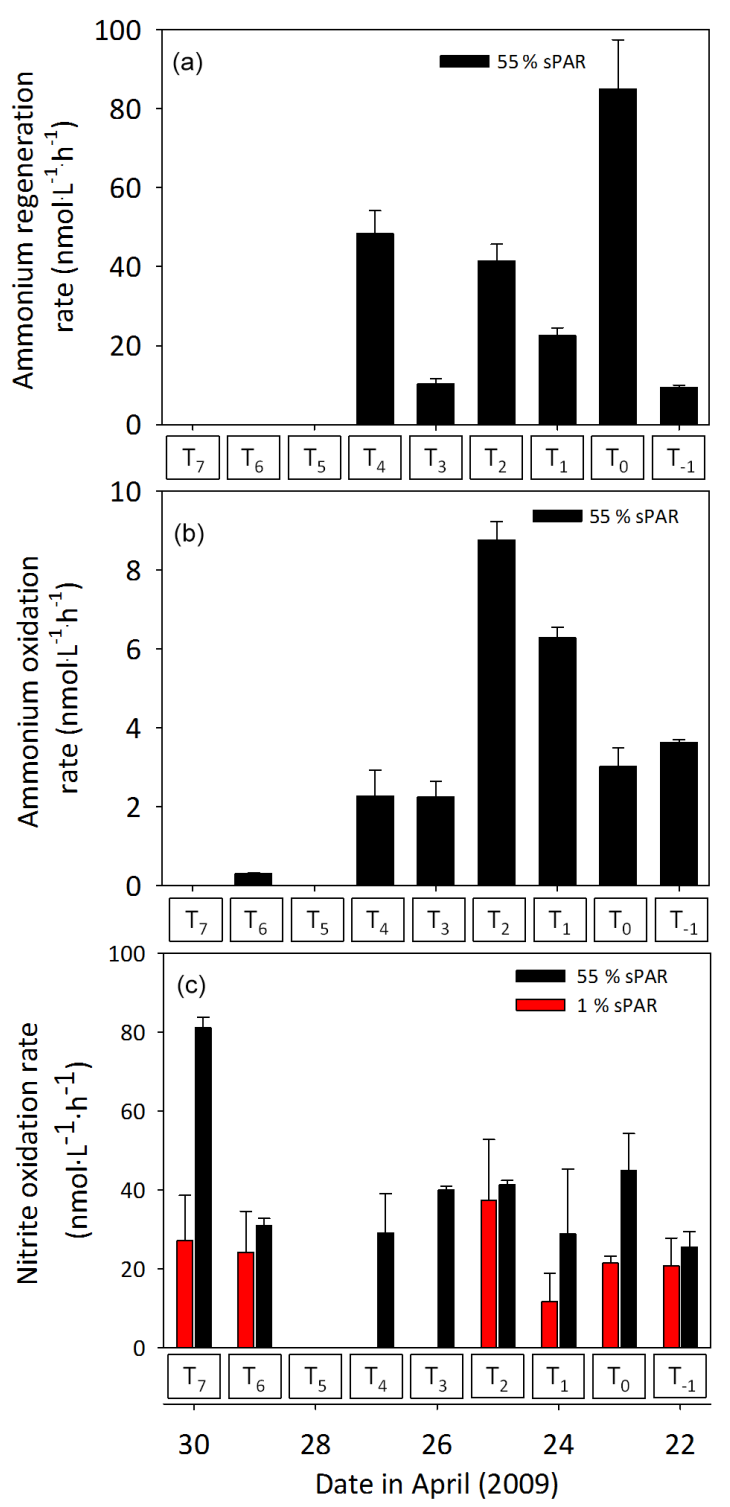

Figure 6. Changes in the rate of ammonium regeneration (a), ammonium oxidation (b), and nitrite oxidation (c) for samples taken within the mixed layer depth at 55 and $1 \%$ sPAR. Error bars represent 1 standard deviation for triplicate rate measurements. Note the reversal of dates to aid comparisons between figures.

of $\mathrm{NO}_{2}^{-}$oxidation. Such a mechanism would be unlikely for the present study as $\mathrm{P}_{1}$ oxygen concentrations exceeded $200 \mu \mathrm{mol} \mathrm{L}^{-1}$ (results not shown), effectively excluding denitrification which is associated with extremely low oxygen or anoxic conditions (Naqvi et al., 2006). We speculate that these observations could be reconciled by a mechanism in which particle-bound nitrifying organisms existed in close physical and chemical association. Diverse sources of evidence support this association (Ward, 2008; Ganesh et al., 2015). Via this mechanism the microbially mediated degradation of particulate organic matter within the microenvi- 
ronment of a recently formed biological particle (Stocker, 2012) would regenerate $\mathrm{NH}_{4}^{+}$, directly supporting $\mathrm{NH}_{4}^{+}$oxidation; resultant $\mathrm{NO}_{2}^{-}$would support $\mathrm{NO}_{2}^{-}$oxidation and regenerated $\mathrm{NO}_{3}^{-}$would be released from particles. In contrast, neither $\mathrm{NH}_{4}^{+}$nor $\mathrm{NO}_{2}^{-}$would be released from particles to an extent that reflected the stoichiometric-rate relationships within, or closely associated with the particle (potentially contributing to the persistent budgetary " $\mathrm{NH}_{4}^{+}$deficit" previously identified in the Iberian upwelling study of Clark et al., 2011). If such a mechanism were to operate, specific tracer methods would underestimate nitrogen regeneration rates (specifically $\mathrm{NH}_{4}^{+}$regeneration and oxidation rates) in ecosystems characteristically enriched in newly formed marine particles. If this were the case, the extent of decoupling would imply that the substantial majority of nitrification within $\mathrm{P}_{1}$ was associated with particles. It is unlikely that the micro-environment of marine particles reflects that of bulk water (Stocker, 2012), offering a rationale for our inability to establish robust relationships between environmental factors and nitrification rates beyond light inhibition, which has limited model development (Bouskill et al., 2011; Füssel et al., 2011; Smith et al., 2014a). Additionally, should such a mechanism operate, direct competition with phytoplankton for $\mathrm{NH}_{4}^{+}$, to which particle-bound nitrifying organisms are subject, would be alleviated to some extent (Smith et al., 2014b).

\subsection{F ratio formulations}

The present study demonstrated that nitrification was measurable from the inception of $\mathrm{P}_{1}$, implying that the fraction of regenerated $\mathrm{NO}_{3}^{-}$progressively increased within days of upwelled water reaching the photic zone. $F$ ratio formulations for $\mathrm{P}_{1}$ are presented in Fig. 7 using simultaneously measured rates of nitrogen assimilation and regeneration. Using the original formulation, the highest $f$ ratio values were derived during the first 3 days of Lagrangian study ( $f=0.44-0.63)$, generally decreasing as $\mathbf{P}_{1}$ advected offshore $(f=0.32-0.38)$. A study of this region by Minas et al. (1982) provided an $f$ ratio value of 0.9 but did not consider the role of $\mathrm{NH}_{4}^{+}$regeneration. A revised value of 0.64 was provided by Minas et al. (1986), comparable to that measured during the earliest stages of this study. Correcting $f$ ratio values for isotope dilution ( $f_{\mathrm{c}}$ ratio) made only minor differences. However, accounting for the fraction of regenerated $\mathrm{NO}_{3}^{-}$(in addition to isotope dilution; $f_{\text {regen }}$ ratio) led to a cumulative decrease in values relative to the original formulation. Results implied that within approximately 6 days, the fraction of regenerated $\mathrm{NO}_{3}^{-}$was greater than $50 \%$ and that the transition from new to a regenerated $\mathrm{NO}_{3}^{-}$pool occurred rapidly (i.e. of the order of days, not weeks). Given the evidence for nitrification in other upwelling systems (Ward, 2005; Fernández et al., 2009; Clark et al., 2011; Benavides et al., 2014), it is likely that $\mathrm{NO}_{3}^{-}$-based exportable production from such systems has been overestimated historically.

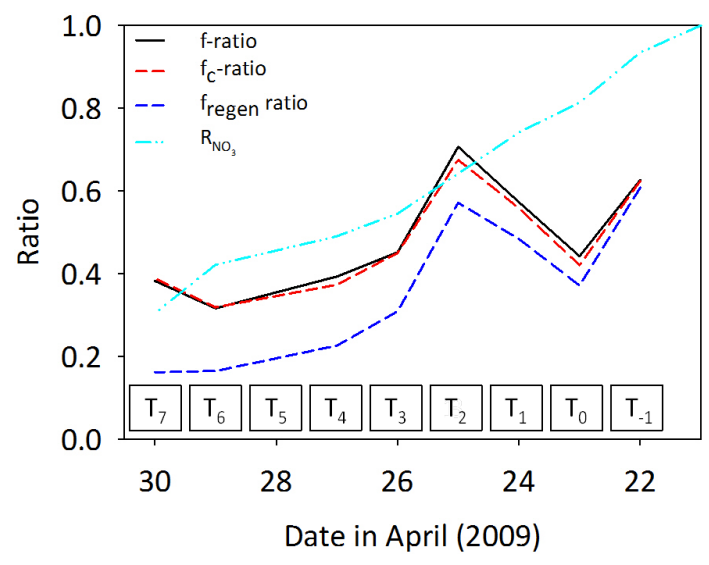

Figure 7. Changes in $f$ ratio representations ( $f$ ratio, $f_{\mathrm{c}}$ ratio corrected for isotope dilution due to nitrogen regeneration, $f_{\text {regen }}$ ratio corrected for isotope dilution and the fraction of the nitrate pool represented by new rather than regenerated nitrate). The fraction of the nitrate pool represented by new nitrate is also presented $\left(R_{\mathrm{NO}_{3}}\right)$. Note the reversal of dates to aid comparisons between figures.

\subsection{Calculating the carbon export of $P_{1}$}

Carbon export supported by new production was estimated using the approach of Eppley and Peterson (1979) as the product of the $f$ ratio and primary production. We compared the original formulation ( $f$ ratio) to alternative formulations: $f_{\mathrm{c}}$ ratios (corrected for isotope dilution) and $f_{\text {regen }}$ ratio (corrected for isotope dilution and regenerated $\mathrm{NO}_{3}^{-}$).

Rees et al. (2011) estimated that the time taken for $P_{1}$ to mature from newly upwelled to open-ocean conditions was approximately 14 days, which we confirmed by the extrapolation of integrated primary production rates along an exponential gradient $\left(\mathrm{PP}=801.72 e^{-0.253 \text { Time }}, r^{2}=0.93\right)$. Rates decreased from $0.69 \mathrm{~mol} \mathrm{C} \mathrm{m}^{-2} \mathrm{~d}^{-1}\left(T_{-1}\right)$ to approximately $0.02 \mathrm{~mol} \mathrm{C} \mathrm{m}^{-2} \mathrm{~d}^{-1}$ on day 14 , comparable to rates reported for the oligotrophic north-east Atlantic (Tilstone et al., 2009). The mean area of $\mathrm{P}_{1}$ was estimated from surface sea temperature images at $1.29 \times 10^{4} \mathrm{~km}^{2}$, while upwelling activity characteristics were also considered. For the purpose of this estimation we assumed that the persistence of upwelling north of $20^{\circ} \mathrm{N}$ enabled the extrapolation of primary production measured during $\mathrm{P}_{1}$ over 12 months. By integrating primary production over the 14-day period between maximum upwelling and open-ocean conditions and extrapolating to the mean filament area we estimated annual primary production of $12.38 \mathrm{Tg} \mathrm{C}$. The fraction of annual productivity available for export derived using the $f$ ratio was $6.19 \mathrm{Tg} \mathrm{C}(50 \%)$; using the $f_{\mathrm{c}}$ ratio exportable production was $6.01 \mathrm{Tg} \mathrm{C}(49 \%)$; using the $\mathrm{f}_{\text {regen }}$ ratio exportable production was $4.73 \mathrm{Tg} \mathrm{C}$ $(38 \%)$. Comparisons with previous estimations are complicated by differences in filament location, geographical area, activity, and integration depth, ranging from $1.12-2.62 \mathrm{Tg} \mathrm{C}$ $\mathrm{yr}^{-1}$ (Helmke et al., 2005) to $3.1 \mathrm{Tg} \mathrm{C} \mathrm{yr}^{-1}$ (Álvarez-Salgado 
et al., 2007), which are of similar order to our $f_{\text {regen }}$ ratio estimates. Within the constraints of our assumptions, results suggest that both isotope dilution and the fraction of previously regenerated $\mathrm{NO}_{3}^{-}$can be important sources of error for nitrogen-based estimations of $\mathrm{C}$ export.

\section{Conclusions}

For open-ocean systems, the limitation to the new production paradigm that $\mathrm{NO}_{3}^{-}$is not necessarily new is now well established; to this we add that even within upwelling regions where genuinely new $\mathrm{NO}_{3}^{-}$is supplied to the photic zone, the fraction of regenerated $\mathrm{NO}_{3}^{-}$increases rapidly. Since the instantaneous ratio of new to regenerated $\mathrm{NO}_{3}^{-}$cannot readily be derived, this adds uncertainty to $f$ ratio values. Upwelling zones are unquestionably highly productive. However, our data indicate that nitrification in these waters is significant. It impacts upon $f$ ratio-derived estimations of new production and carbon export by diluting ${ }^{15} \mathrm{NO}_{3}^{-}$tracer and facilitating a transition in $\mathrm{NO}_{3}^{-}$pool provenance from a source of new towards a source of regenerated nitrogen.

Acknowledgements. We thank Carol Robinson (chief scientist), Ricardo Torres, and Phil Nightingale for cruise leadership and $\mathrm{SF}_{6}$ mapping, and the officers and crew of the RRS Discovery cruise D338. We thank NEODAAS for providing satellite data to SOLAS-ICON. We thank Lisa Al-Moosawi for isotope ratio mass spectrometry analysis and two anonymous reviewers for constructive comments during the review process. This study was supported by NERC grant NE/C517176/1 (UK-SOLAS) and by Theme 2 of NERC Oceans 2025.

Edited by: G. Herndl

\section{References}

Álvarez-Salgado, X. A., Beloso, S., Joint, I., Nogueira, E., Chou, L., Perez, F. F., Groom, S., Cabanas, J. M., Rees, A. P., and Elskens, M.: New production of the NW Iberian shelf during the upwelling season over the period 1982-1999, Deep-Sea Res. Part I, 49, 1725-1739, doi:10.1016/S0967-0637(02)00094-8, 2002.

Álvarez-Salgado, X. A., Arístegui, J., Barton, E. D., and Hansell, D. A.: Contribution of upwelling filaments to offshore carbon export in the subtropical Northeast Atlantic Ocean, Limnol. Oceanogr., 52, 1287-1292, doi:10.4319/lo.2007.52.3.1287, 2007.

Arístegui, J., Álvarez-Salgado, X. A., Barton, E. D., Figueiras, F. G., Hernández-León, S., Roy, C., and Santos, A. M. P.: Oceanography and fisheries of the Canary Current Iberian region of the Eastern North Atlantic, 877-931, in: The global coastal ocean: Interdisciplinary regional studies and syntheses, edited by: Robinson, A. and Bronk, K. H., Harvard Univ. Press, 2006.

Arístegui, J., Barton, E. D., Álvarez-Salgado, X. A., Santos, M. P., Figueiras, F. G., Kifani, S., Hernández-León, S., Mason, E.,
Machú, E., and Demarcq, H.: Sub-regional ecosystem variability in the Canary Current upwelling, Prog. Oceanogr, 83, 33-43, doi:10.1016/j.pocean.2009.07.031, 2009.

Baker, A. R., Kelly, S. D., Biswa, K. F., Witt, M., and Jickells, T. D.: Atmosphericdeposition of nutrients to the Atlantic Ocean, Geophys. Res. Lett., 30, 2296, doi:10.1029/2003GL018518, 2003.

Beman, J. M., Sachdeva, R., and Fuhrman, J. A.: Population ecology of nitrifying Archaea and bacteria in the Southern California Bight, Environmental Microbiol., 12, 1282-1292, doi:10.1111/j.1462-2920.2010.02172.x, 2010.

Beman, J. M., Shih, J. L., and Popp, B. N.: Nitrite oxidation in the upper water column and oxygen minimum zone of the eastern tropical North Pacific Ocean, Int. Soc. Micro. Ecol., 7, 21922205, doi:10.1038/ismej.2013.96, 2013.

Benavides M., Arístegui, J., Agawin, N. S. R., Álvarez-Salgado, X. A., Álvarez, M., and Troupin, C.: Low contribution of $\mathrm{N}_{2}$ fixation to new production and excess nitrogen in the subtropical northeast Atlantic margin, Deep-Sea Res. I, 81, 36-48, doi:10.1016/j.dsr.2013.07.004, 2013.

Benavides M., Santana-Falcón Y., Wasmund, N., and Arístegui, J.: Microbial uptake and regeneration of inorganic nitrogen off the coastal Namibian upwelling system, J. Mar. Sys., 140, 123-129, doi:10.1016/j.jmarsys.2014.05.002, 2014.

Blackburn, T. H.: Method for measuring rates of $\mathrm{NH}_{4}^{+}$turnover in anoxic marine sediments, using ${ }^{15} \mathrm{~N}^{-\mathrm{NH}_{4}^{+}}$dilution technique, Appl. Environ. Microbiol., 37, 760-765, 1979.

Bode, A., Barquero, S., Gonzalez, N., Alvarez-Ossorio, M. T., and Varela, M.: Contribution of heterotrophic plankton to nitrogen regeneration in the upwelling ecosystem of A Coruña (NW Spain), J. Plankton Res., 26, 11-28, doi:10.1093/plankt/fbh003, 2004.

Bouskill, N. J., Eveillard, D., Chien, D., Jayakumar, A., and Ward, B. B: Environmental factors determining ammoniaoxidizing organism distribution and diversity in marine environments, Environ. Microbiol., 14, 714-729, doi:10.1111/j.14622920.2011.02623.x, 2011.

Bronk, D. A. and Glibert, P. M.: Contrasting patterns of dissolved organic nitrogen release by two size fractions of estuarine plankton during a period of rapid $\mathrm{NH}_{4}^{+}$consumption and $\mathrm{NO}_{2}^{-}$production, Mar. Ecol. Prog. Ser., 96, 291-299, 1993.

Bronk, D. A. and Ward, B. B.: Gross and net nitrogen uptake and DON release in the euphotic zone of Monterrey Bay, California, Limnol. Oceanogr., 44, 573-585, 1999.

Bronk, D. A. and Steinberg, D. K.: Nitrogen regeneration, in: Nitrogen in the Marine Environment, edited by: Capone, D., Bronk, D. A., Mulholland, M. R., and Carpenter, E. J., Elsevier Press, 385467, 2008.

Bronk, D. A., Glibert, P. M., and Ward, B. B.: Nitrogen uptake, dissolved organic nitrogen release, and new production, Science, 265, 1843, doi:10.1126/science.265.5180.1843, 1994

Brzezinski, M. A.: The Si-C-N ratio of marine diatoms - Interspecific variability and the effect of some environmental variables, J. Phycol., 21, 347-357, doi:10.1111/j.0022-3646.1985.00347.x, 1985.

Caperon, J., Schell, D., Hirota, J., and Laws, E: Ammonium excretion rates in Kaneohe Bay, Hawaii, measured by a ${ }^{15} \mathrm{~N}$ isotope dilution technique, Mar. Biol., 54, 33-40, doi:10.1007/BF00387049, 1979. 
Chavez, F. and Messié, M.: A comparison of Eastern Boundary Upwelling Ecosystems, Prog. Oceaogr., 83, 80-96, doi:10.1016/j.pocean.2009.07.032, 2009.

Clark, D. R., Flynn, K. J., and Owens, N. J. P.: The large capacity for dark nitrate-assimilation in diatoms may overcome nitrate limitation of growth, New Phytol., 155, 101-108, doi:10.1046/j.14698137.2002.00435.x, 2002.

Clark, D. R., Fileman, T. W., and Joint, I.: Determination of ammonium regeneration rates in the oligotrophic ocean by gas chromatography/mass spectrometry, Mar. Chem., 98, 121-130, doi:10.1016/j.marchem.2005.08.006, 2006.

Clark, D. R., Rees, A. P., and Joint, I.: A method for the determination of nitrification rates in oligotrophic marine seawater by gas chromatography/mass spectrometry, Mar. Chem., 103, 8496, doi:10.1016/j.marchem.2006.06.005, 2007.

Clark, D. R., Rees, A. P., and Joint, I.: Ammonium regeneration and nitrification rates in the oligotrophic Atlantic Ocean: Implications for new production estimates, Limnol. Oceanogr., 53, 5262, doi:10.4319/lo.2008.53.1.0052, 2008

Clark, D. R., Miller, P. I., Woodward, E. M. S., and Rees, A. P.: Inorganic nitrogen assimilation and regeneration in the coastal upwelling region of the Iberian Peninsula, Limnol. Oceanogr., 56, 1689-1702, doi:10.4319/lo.2011.56.5.1689, 2011.

Clark, D. R., Brown, I. J., Rees, A. P., Somerfield, P. J., and Miller, P. I.: The influence of ocean acidification on nitrogen regeneration and nitrous oxide production in the northwest European shelf sea, Biogeosciences, 11, 4985-5005, doi:10.5194/bg-114985-2014, 2014.

D'Asaro, E. A.: Lagrangian trajectories on the Oregon shelf during upwelling, Cont. Shelf Res., 24, 1421-1436, doi:10.1016/j.csr.2004.06.003, 2004.

Deutsch, C., Sarmiento, J. L., Sigman, D. M., Gruber, N., and Dunne, J. P.: Spatial coupling of nitrogen inputs and losses in the ocean, Nature, 445, 163-167, doi:10.1038/nature05392, 2007.

Dickson, M. L. and Wheeler, P. A.: Nitrate uptake rates in a coastal upwelling regime - A comparison of PN-specific, absolute and chl a-specific rates, Limnol. Oceanogr., 40, 533-543, doi:10.4319/lo.1995.40.3.0533, 1995.

Dugdale, R. C. and Goering, J. J.: Uptake of new and regenerated forms of nitrogen in primary productivity, Limnol. Oceanogr., 12, 196-206, doi:10.4319/lo.1967.12.2.0196, 1967.

Dugdale, R. C., Wilkerson, F. P., and Morel, A.: Realization of new production in coastal upwelling areas: A means to compare relative performance, Limnol. Oceanogr., 35, 822-829, doi:10.4319/lo.1990.35.4.0822, 1990.

Eppley, R. W. and Peterson, B. J.: Particulate organic matter flux and planktonic new production in the deep ocean, Nature, 282, 677-680, doi:10.1038/282677a0, 1979.

Fernández, C. and Farías, L.: Assimilation and regeneration of inorganic nitrogen in a coastal upwelling system: ammonium and nitrate utilisation, Mar. Ecol. Prog. Ser., 451, 1-14, doi:10.3354/meps09683, 2012.

Fernández, C., Raimbault, P., Garcia, N., and Rimmelin, P.: An estimation of annual new production and carbon fluxes in the northeast Atlantic Ocean during 2001, J. Geophys. Res., 110, C07S13, doi:10.1029/2004JC002616, 2005.

Fernández, C., Farías, L., and Alcaman, M. E.: Primary production and nitrogen regeneration processes in surface waters of the Peruvian upwelling system, Prog. Oceanogr., 83, 159-168, doi:10.1016/j.pocean.2009.07.010, 2009.

Fernández-Urruzola, I., Osma, N., Packard, T. T., Gómez, M., and Postel, L.: Distribution of zooplankton biomass and potential metabolic activities across the northern Benguela upwelling system, J. Marine Syst., 140, 138-149, doi:10.1016/j.jmarsys.2014.05.009, 2014.

Flohr, A., van der Plas, A. K., Emeis, K.-C., Mohrholz, V., and Rixen, T.: Spatio-temporal patterns of $\mathrm{C}: \mathrm{N}: \mathrm{P}$ ratios in the northern Benguela upwelling system, Biogeosciences, 11, 885897, doi:10.5194/bg-11-885-2014, 2014.

Flynn, K. J., Clark, D. R., and Owens, N. J. P.: Modelling suggests that optimization of dark nitrogen-assimilation need not be a critical selective feature in phytoplankton, New Phytol., 155, 109119, doi:10.1046/j.1469-8137.2002.00436.x, 2002.

Füssel, J., Lam, P., Lavik, G., Jensen, M. M., Holtappels, M., Günter, M., and Kuypers, M. M. M.: Nitrite oxidation in the Namibian oxygen minimum zone, ISME Journal, 6, 1200-1209, doi:10.1038/ismej.2011.178, 2011

Ganesh, S. Bristow, L. A., Larsen, M., Sarode, N., Thamdrup, B., and Stewart, F. J.: Size-fraction partitioning of community gene transcription and nitrogen metabolism in a marine oxygen minimum zone, ISME, 9, 2682-2696, doi:10.1038/ismej.2015.44, 2015.

Gilpin, L. C., Davidson, K., and Robertsb, E.: The influence of changes in nitrogen: silicon ratios on diatom growth dynamics, J. Sea Res., 51, 21-35, doi:10.1016/j.seares.2003.05.005, 2004.

Glibert, P. M., Lipshultz, F., McCarthy, J. J., and Altabet, M. A.: Isotope dilution models of uptake and remineralization of ammonium by marine plankton, Limnol. Oceanogr., 27, 639-650, doi:10.4319/lo.1982.27.4.0639, 1982.

Gregor, L. and Monteiro, P. M. S.: Seasonal cycle of N : P:TA stoichiometry as a modulator of $\mathrm{CO}_{2}$ buffering in eastern boundary upwelling systems, Geophys. Res. Lett. 40, 5429-5434, doi:10.1002/2013GL058036, 2013.

Helmke, P., Romero, O., and Fischer, G.: Northwest African upwelling and its effect on offshore organic carbon export to the deep sea, Global Biogeochem. Cy., 19, GB4015, doi:10.1029/2004GB002265, 2005.

Intergovernmental Oceanographic Commission, Paris (France), Protocols for the Joint Global Flux Study (JGOFS) core measurements, Manuals Guides 29, 1994.

Jickells, T. and Moore, C. M.: The importance of atmospheric deposition for ocean productivity, Annu. Rev. Ecol. Evol. Syst., 46 , 481-501, doi:10.1146/annurev-ecolsys-112414-054118, 2015.

Joint, I., Rees, A. P., and Woodward, E. M. S.: Primary production and nutrient assimilation in the Iberian upwelling in $\mathrm{Au}-$ gust 1998, Prog. Oceanogr., 51, 303-320, doi:10.1016/S00796611(01)00072-6, 2001a.

Joint, I., Inall, M., Torres, R., Figueiras, F. G., Álvarez-Salgado, X. A., Rees, A. P., and Woodward, E. M. S.: Two Lagrangian experiments in the Iberian Upwelling System: Tracking an upwelling event and an offshore filament, Prog. Oceanogr., 51, 221-248, doi:10.1016/S0079-6611(01)00068-4, 2001b.

Kanda, J., Laws, E. A., Saino, S. T., and Hattori, A.: An evaluation of isotope dilution effect from conventional data sets of ${ }^{15} \mathrm{~N}$ uptake experiments, J. Plankton Res., 19, 79-90, doi:10.1093/plankt/9.1.79, 1987. 
Kudela, R. M., Cochlan, W. P., and Dugdale, R. C.: Carbon and nitrogen uptake response to light by phytoplankton during an upwelling event, J. Plankton Res., 19, 609-630, doi:10.1093/plankt/19.5.609, 1997.

Loucaides, S., Tyrrell, T., Achterberg, E. P., Torres, R., Nightingale, P. D., Kitidis, V., Serret, P., Woodward, M., and Robinson, C.: Biological and physical forcing of carbonate chemistry in an upwelling filament off northwest Africa: Results from a Lagrangian study, Global Biogeochem. Cy., 26, GB3008, doi:10.1029/2011GB004216, 2012.

Lipshultz, F., Wofsy, S. C., Ward, B. B., Codispoti, L. A., Freidrich, G., and Elkins, J. W.: Bacterial transformations of inorganic nitrogen in the oxygen deficient waters of the Eastern Tropical South Pacific Ocean, Deep Sea Res., 37, 1513-1541, 1990.

Martin, A. P. and Pondaven, P.: New production and nitrification in the western subtropical North Atlantic: A modelling study, Global Biogeochem. Cy., 20, GB4014, doi:10.1029/2005GB002608, 2006.

Meunier, T., Barton, E. D., Barreiro, B., and Torres, R.: Upwelling filaments off Cap Blanc: Interaction of the NW African upwelling current and the Cape Verde frontal zone eddy field?, J. Geophys. Res., 117, C08031, doi:1029/2012JC007905, 2012.

Miller, P., Groom, S., McManus, A., Selley, J., and Mironnet, N.: Panorama: A semi-automated AVHRR and CZCS system for observation of coastal and ocean processes, RSS97: Observations and Interactions, Proceedings of the Remote Sensing Society, 539-544, 1997.

Minas, T., Packard, T., Minas, M., and Coste, B.: An analysis of the production-regeneration system in the coastal upwelling area off N.W. Africa based on oxygen, nitrate and ammonium distribution, J. Mar. Res., 40, 615-641, 1982.

Minas, H. J., Minas, M., and Packard, T. T.: Productivity in upwelling areas deduced from hydrographic and chemical fields, Limnol. Oceanogr., 31, 1182-1206, 1986.

Mitra, A., Flynn, K. J., Burkholder, J. M., Berge, T., Calbet, A., Raven, J. A., Granéli, E., Glibert, P. M., Hansen, P. J., Stoecker, D. K., Thingstad, F., Tillmann, U., Våge, S., Wilken, S., and Zubkov, M. V.: The role of mixotrophic protists in the biological carbon pump, Biogeosciences, 11, 995-1005, doi:10.5194/bg11-995-2014, 2014.

Mittelstaedt, E.: The ocean boundary along the northwest African coast: Circulation and oceanographic properties at the sea surface, Prog. Oceanogr., 26, 307-355, doi:10.1016/00796611(91)90011-A, 1991.

Moore, C. M., Mills, M. M., Achterberg, E. P., Geider, R. J., LaRoche, J., Lucas, M. I., McDonagh, E. L., Pan, X., Poulton, A. J., Rijkenberg, M. J. A., Suggett, D., Ussher, S. J., and Woodward, E. M. S.: Large-scale distribution of Atlantic nitrogen fixation controlled by iron availability, Nature Geosci., 2, 867-871, doi:10.1038/ngeo667, 2009.

Moore, C. M., Mills, M. M., Arrigo, K. R., Berman-Frank, I., Bopp, L., Boyd, P. W., Galbraith, E. D., Geider, R. J., Guieu, C., Jaccard, S. L., Jickells, T. D., La Roche, J., Lenton, T. M., Mahowald, N. M., Marañón, E., Marinov, I., Moore, J. K., Nakatsuka, T., Oschlies, A., Saito, M. A., Thingstad, T. F., Tsuda, A., and Ulloa, O.: Processes and patterns of oceanic nutrient limitation, Nature Geosci., 6, 701-710, doi:10.1038/ngeo1765, 2013.

Moschonas, G., Gowen, R. J., Stewart, B. M., and Davidson, K.: Nitrogen dynamics in the Irish Sea and adjacent shelf waters: An exploration of dissolved organic nitrogen, Estuar. Coast. Shelf Sci., 164, 276-287, doi:10.1016/j.ecss.2015.07.030, 2015.

Naqvi, S. W. A., Naik, H., Pratihary, A., D’Souza, W., Narvekar, P. V., Jayakumar, D. A., Devol, A. H., Yoshinari, T., and Saino, T.: Coastal versus open-ocean denitrification in the Arabian Sea, Biogeosciences, 3, 621-633, doi:10.5194/bg-3-621-2006, 2006.

Nightingale, P. D., Malin, G., Law, C. S., Watson, A. J., Liss, P. S., Liddicoat, M. I., Boutin, J., and Upstill-Goddard, R. C.: In situ evaluation of air-sea gas exchange parameterizations using novel conservative and volatile tracers, Global Biogeoch. Cy., 14, 373 387, doi:10.1029/1999GB900091, 2000.

Nowald, N., Iversen, M. H., Fischer, G., Ratmeyer, V., and Wefer, G.: Time series of in-situ particle properties and sediment trap fluxes in the coastal upwelling filament off Cape Blanc, Mauritania, Prog. Oceanogr., 137, 1-11, doi:10.1016/j.pocean.2014.12.015, 2015.

Olson, R. J.: Differential photoinhibition of marine nitrifying bacteria: a possibly mechanisms for the formation of the primary nitrite maximum, J. Mar. Res., 39, 227-238, 1981.

Pauly, D. and Christensen, V.: Primary production required to sustain global fisheries, Nature, 374, 255-257, doi:10.1038/374255a0, 1995.

Postel, L., Mohrholz, V., and Packard, T. T.: Upwelling and successive ecosystem response in the Northern Benguela Region - an in situ experiment, J. Marine Syst., 140, 73-81, doi:10.1016/j.jmarsys.2014.07.014, 2014.

Powell, C. F., Baker, A. R., Jickells, T. D., Bange, H. W., Chance, R. J., and Yodle, C.: Estimation of the Atmospheric Flux of Nutrients and Trace Metals to the Eastern Tropical North Atlantic Ocean, J. Atmos. Sci., 72, 4029-4045, doi:10.1175/JAS-D-150011.1, 2015.

Probyn, T. A.: Ammonium regeneration by microplankton in an upwelling environment, Mar. Ecol. Prog. Ser., 37, 53-64, 1987.

Probyn, T. A.: Size-fractionated measurements of nitrogen uptake in aged upwelled waters: Implications for pelagic food webs, Limnol. Oceanogr., 35, 202-210, doi:10.4319/lo.1990.35.1.0202, 1990.

Raimbault, P. and Garcia, N.: Evidence for efficient regenerated production and dinitrogen fixation in nitrogen-deficient waters of the South Pacific Ocean: impact on new and export production estimates, Biogeosciences, 5, 323-338, doi:10.5194/bg-5323-2008, 2008.

Rain-Franco, A., Muñoz, C., and Fernández, C.: Ammonium production off central Chile $\left(36^{\circ} \mathrm{S}\right)$ by photodegradation of phytoplankton derived and marine dissolved organic matter, PLosOne, 9, e100224, doi:10.1371/journal.pone.0100224, 2014.

Rees, A. P., Brown, I. J., Clark, D. R., and Torres, R.: The Lagrangian progression of nitrous oxide within filaments formed in the Mauritanian upwelling, Geophys. Res. Lett., 38, L21606, doi:10.1029/2011GL049322, 2011.

Santoro, A. E., Casciotti, K. L., and Francis, C. A.: Activity, abundance and diversity of nitrifying archaea and bacteria in the central California Current, Environ. Microbiol., 12, 1989-2006, doi:10.1111/j.1462-2920.2010.02205.x, 2010.

Shannon, L. V. and Field, J. G.: Are fish stocks food limited in the southern Benguela pelagic ecosystem?, Mar. Ecol. Prog. Ser., 22, 7-19, doi:10.3354/meps022007, 1985.

Smith, J. M., Casciotti, K. L., Chavez, F. P., and Francis, C. A.: Differential contribution of archaeal ammonia oxidizer ecotypes 
to nitrification in coastal surface waters, ISME, 8, 1704-1714, doi:10.1038/ismej.2014.11, 2014a.

Smith, K. M., Chavez, F. P., and Francis, C. A.: Ammonium uptake by phytoplankton regulates nitrification in the sunlit ocean, PLoS ONE, 9, e108173, doi:10.1371/journal.pone.0108173, 2014b.

Sohm, J., Hilton, J., Noble, A. E., Zehr, J. P., Saito, M., and Webb, E. A.: Nitrogen fixation in the South Atlantic Gyre and the Benuela Upwelling System, Geophys. Res. Lett., 38, L16608, doi:10.1029/2011GL048315, 2011.

Staal, M. S., Lintel Heckert, S., Brummer, G. J. A., Veldhuis, M., Sikkens, C., Persijn, S., and Stal, L. J.: Nitrogen fixation along north-south transect in the eastern Atlantic ocean, Limnol. Oceanogr., 52, 1305-1316, doi:10.4319/lo.2007.52.4.1305, 2007.

Stocker, R.: Marine microbes see a sea of gradients, Science, 338, 628-633, doi:10.1126/science.1208929, 2012.

Sweeney, R. E., Liu, K. K., and Kaplan, I. R.: Oceanic nitrogen isotopes and their uses in determining the source of sedimentary nitrogen, N. Z. Depart. Sci. Ind. Res. Bull., 220, 9-26, 1978.

Tilstone, G., Smyth, T., Poulton, A., and Hutson, R.: Measured and remotely sensed estimates of primary production in the Atlantic Ocean from 1998 to 2005, Deep-Sea Res. II, 56, 918-930, doi:10.1016/j.dsr2.2008.10.034, 2009.

Tomczak, M. and Godfrey, J. S.: Regional Oceanography: An Introduction (second ed) Daya, Delhi, India, 390 pp., 2003.

Varela, M. M., Barquero, S., Bode, A., Fernández, E., González, N., Teira, E., and Varela, M.: Microplanktonic regeneration of ammonium and dissolved organic nitrogen in the upwelling area of the NW of Spain: relationships with dissolved organic carbon production and phytoplankton size-structure, J. Plank. Res., 25, 719-736, 2003.

Varela, M., Bode, A., Fernández, E., Gonzales, N., Kitidis, V., Varela, M., and Woodward, E. M. S.: Nitrogen uptake and dissolved organic nitrogen release in planktonic communities characterized by phytoplankton size structure in the central North Atlantic, Deep Sea Res. I, 52, 1637-1661, doi:10.1016/j.dsr.2005.03.007, 2005.
Wafar, M., L'Helguen, S., Raikar, V., Maguer, J. F., and Corre, P. L.: Nitrogen uptake by size-fractionated plankton in permanently well-mixed temperate coastal waters, J. Plank. Res., 26, 12071218, doi:10.1093/plankt/fbh110, 2004.

Ward, B. B.: Temporal variability in nitrification rates and related biogeochemical factors in Monterey Bay, California, USA, Mar. Ecol. Prog. Ser., 292, 97-109, doi:10.3354/meps292097, 2005.

Ward, B. B.: Nitrogen in the Marine Environment, in: Nitrogen in the Marine Environment, edited by: Capone, D., Bronk, D. A., Mulholland, M. R., and Carpenter, E. J., Elsevier Press, 199-261, 2008.

Wasmund, N., Struck, U., Hansen, A., Flohr, A., Nausch, G., Gruttmuller, A., and Voss, M.: Missing nitrogen fixation in the Benguela region, Deep-Sea Res. I, 106, 30-41, doi:10.1016/j.dsr.2015.10.007, 2015 .

Wilkerson, F. P. and Dugdale, R. C.: The use of large shipboard barrels and drifters to study the effects of coastal upwelling on phytoplankton dynamics, Limnol. Oceanogr., 32, 368-382, doi:10.4319/lo.1987.32.2.0368, 1987.

Wilkerson, F. P. and Dugdale, R. C.: Coastal Upwelling, in: Nitrogen in the Marine Environment, edited by: Capone, D., Bronk, D. A., Mulholland, M. R., and Carpenter, E. J., Elsevier Press, 765-801, 2008.

Woodward, E. M. S. and Rees, A. P.: Nutrient distributions in an anticyclonic eddy in the North East Atlantic Ocean, with reference to nanomolar ammonium concentrations, Deep-Sea Res., 48, 775-794, doi:10.1016/S0967-0645(00)00097-7, 2001.

Zindler, C., Peeken, I., Marandino, C. A., and Bange, H. W.: Environmental control on the variability of DMS and DMSP in the Mauritanian upwelling region, Biogeosciences, 9, 1041-1051, doi:10.5194/bg-9-1041-2012, 2012. 